\title{
Novel Piperidine and 3,4-dihydro-2H-pyrrole Alkaloids from Tilia platyphyllos and Tilia cordata Flowers
}

\author{
Authors \\ Nico Symma ${ }^{1}$, Marek Bütergerds ${ }^{1}$, Jandirk Sendker ${ }^{1}$, Frank Petereit ${ }^{1}$, Alexander Hake ${ }^{1}$, Martina Düfer ${ }^{2}$, Andreas Hensel ${ }^{1}$ \\ Affiliations \\ 1 Institute of Pharmaceutical Biology and Phytochemistry, \\ University of Münster, Münster, Germany \\ 2 Institute of Pharmaceutical and Medicinal Chemistry- \\ Pharmacology, University of Münster, Münster, Germany \\ Key words \\ Tilia platyphyllos, Tilia cordata, Malvaceae, Tiliae flos, alkaloid, \\ dihydropyrrole, piperidine

$\begin{array}{ll}\text { received } & \text { October } 26,2020 \\ \text { accepted after revision } & \text { December } 15,2020 \\ \text { published online } & \text { January } 12,2021\end{array}$ \\ Bibliography \\ Planta Med 2021; 87: 686-700 \\ DOI 10.1055/a-1340-0099 \\ ISSN 0032-0943 \\ (C) 2021. Thieme. All rights reserved. \\ Georg Thieme Verlag KG, Rüdigerstraße 14, \\ 70469 Stuttgart, Germany \\ Correspondence \\ Prof. Dr. Andreas Hensel \\ Institute of Pharmaceutical Biology and Phytochemistry, \\ University of Münster \\ Corrensstraße 48, 48149 Münster, Germany \\ Phone: + 492518333380 , Fax: + 492518338341 \\ ahensel@uni-muenster.de \\ $\bigoplus \begin{aligned} & \text { Supplementary material is available under } \\ & \text { https://doi.org/10.1055/a-1340-0099 }\end{aligned}$

\section{ABSTRACT} \\ Lime flowers, traditionally used for medical purposes for the \\ treatment of symptoms of the common cold and mental \\ stress, consist of the dried inflorescences including the floral \\ bracts of Tilia cordata, Tilia platyphyllos, Tilia $\times$ vulgaris, or mix- \\ tures thereof. During phytochemical investigations, 6 differ- \\ ent alkaloids - not described until now - were detected in \\ T. cordata and T. platyphyllos flowers. They have been isolated \\ and characterized as alkaloids with a dihydro-pyrrole and a \\ piperidine substructure, respectively. Compounds $1 \mathrm{a}$ and $1 \mathrm{~b}$ \\ (tiliines $\mathrm{A}$ and $\mathrm{B}$ ) are characterized as 2 diastereomers contain- \\ ing a 2-methyl-3,4-dihydro-2H-pyrrol-3-ol, connected via a C- \\ 10 alkyl chain to a $O$-glucosylated hydroquinone moiety. \\ Compounds $2 \mathrm{a}$ and $\mathbf{2 b}$ (tiliamines $\mathrm{A}$ and $\mathrm{B}$ ) are diastereomers \\ of a 2-methyl-substituted piperidin-3-ol, coupled via a C-9 al- \\ $\mathrm{kyl}$ chain again to an $\mathrm{O}$-glucosylated hydroquinone moiety. \\ Compounds $3 \mathrm{a}$ and $3 \mathrm{~b}$ (tilacetines $\mathrm{A}$ and $\mathrm{B}$ ) are 3-O-acety- \\ lated derivatives of tiliamines. Quantification of the 6 alka- \\ loids by HPLC-ESI-qTOF analysis indicated the presence of all \\ alkaloids in $T$. cordata flowers and T. platyphyllos flowers, \\ bracts, and leaves, with tiliines $A$ and $B$ and tilacetines $A$ and \\ $B$ being the major compounds. Acetone/water turned out be \\ the best extraction solvent for the alkaloids, but ethanol and \\ ethanol/water mixtures also can be used for effective extrac- \\ tion. Furthermore, the alkaloids are found in hot water ex- \\ tracts, which are typically used in the traditional medicine.
}

\section{Introduction}

According to the European Pharmacopoeia, lime flower (Tiliae flos) is an herbal material consisting of the dried inflorescences including the floral bracts of Tilia cordata MILL. (small-leaved lime), Tilia platyphyllos SCOP. (large-leaved lime), Tilia $\times$ vulgaris HEYNE (hybrid of both), or their mixtures. The genus Tilia belongs to the plant family of Malvaceae. The European Medicinal Agency has registered the medical use of lime flower as a traditional herbal medicinal product for the relief of symptoms of common cold and mental stress [1-3]. The quality of lime flower for medical use is specified in the respective monograph of the European Pharmacopoeia [3].
From the phytochemical point of view, the herbal material is characterized by the presence of about $1 \%$ of a complex mixture of flavonoids, mainly glycosides of quercetin (e.g., rutin, hyperosid, quercitrin, isoquercitrin, quercetin-3,7-di-O-rhamnoside, quercetin-rhamno-xyloside, quercetin-3-O-gluco-7-O-rhamnoside) and kaempferol glycosides (e.g., astragalin, tilirosid, kaempferol-3-O-gluco-7-O-rhamnoside, kaempferol-3,7-di-O-rhamnoside) [4-6]. Polysaccharides (about 10\%) are mainly composed of acidic arabinogalactans [7]. Volatile oil (0.02 to $0.1 \%$ ) consists mainly of monoterpenes (linalool, geraniol, 1,8-cineol, carvone, camphor, thymol, carvacrol), phenylpropanoids (anethol, eugenol), benzyl alcohol, 2-phenylethanol, and the respective acetic acid and benzoic acid esters [8]. The herbal material contains a 
high content of oligomeric and polymeric proanthocyanidins, mainly composed of catechin and epicatechin building blocks [9]. Furthermore, organic acids (e.g., caffeic acid, $p$-coumaric acid, and esters), coumarins (e.g., scopoletin, fraxin-8- $\beta$-D-glucoside), amino acids, carbohydrates, saponins, and tocopherol have been described [1,2].

The traditional use of lime flower preparations has not been rationalized sufficiently. Polysaccharides from lime flower are known to form strong bioadhesive layers on buccal epithelia, leading to rehydration and shielding of infected epithelia. These bioadhesive and mucilaginous properties could potentially explain a reduction of cough intensity and the traditional use of the herbal material for common cold [10]. Central effects of the volatile oil have been discussed to be responsible for sedation and reduced motility [11]. Increased perspiration by the herbal material as part of the treatment of fever in patients suffering from a common cold has not been proven until now. It also has not been linked to any natural products of the herbal material. Surprisingly, a detailed phytochemical reinvestigation of the herbal material by our group revealed the presence of alkaloids in hydroacetonic and hydroalcoholic extracts from lime flower. The present contribution reports on the structural characterization of so far undescribed glycosylated piperidine and 3,4-dihydro-2H-pyrrole alkaloids. Although alkaloids are known for the Malvaceae plant family [12-14], this is the first report on alkaloids from the genus Tilia.

\section{Results and Discussion}

Lime flower herbal material was extracted with acetone/water $(7: 3 \mathrm{v} / \mathrm{v})$ according to a protocol typically used for extracting polar and semi-polar constituents from plant material [9]. The detailed extraction and separation scheme, as well as the respective yields, are shown in $>$ Fig. $\mathbf{1}$.

Analysis of the obtained extract A by reversed-phase HPLC coupled with (+)-ESI-qTOF-MS showed 6 major peaks ( $\mathrm{m} / \mathrm{z} 510$, 512 , and 554) and 1 minor peak ( $\mathrm{m} / \mathrm{z} 552)$ in the base peak chromatogram (Fig. 1S, Supporting Information). Even-numbered $\mathrm{m} / \mathrm{z}$ values were indicative for compounds with an odd number of nitrogen atoms. In-depth literature search on nitrogenous natural products from the genus Tilia did not reveal any information on such compounds in the respective mass range. To clarify the identity of these compounds, the extract A was further fractionated by solid phase extraction (SPE) using a strong cationic exchanger. This protocol yielded 4 different fractions (acidic fraction, neutral fraction, basic fraction, and wash eluate). The sought nitrogenous compounds were exclusively detected in the basic fraction $\mathrm{B}$, which was eluted with $5 \% \mathrm{NH}_{3}$ in methanol/acetonitrile $(1: 1 \mathrm{v} / \mathrm{v})$. LC-HR-MS analysis of this fraction additionally indicated the presence of a variety of amino acids. Fraction B was further fractionated on a Sephadex LH-20 column. This procedure yielded a fraction C, which consisted of the desired compounds, while all amino acids had been removed. Fraction $C$ was finally subjected to preparative RP18-HPLC, which resulted in the isolation of 6 substances (1a/1b, $2 a / 2 b, 3 a / 3 b)$, consisting of 3 pairs of isobaric compounds, according to LC-HR-MS analysis. Structure elucidation by $1 \mathrm{D}$ - and 2D-NMR and LC-ESI-qTOF-HR-MS revealed previ-

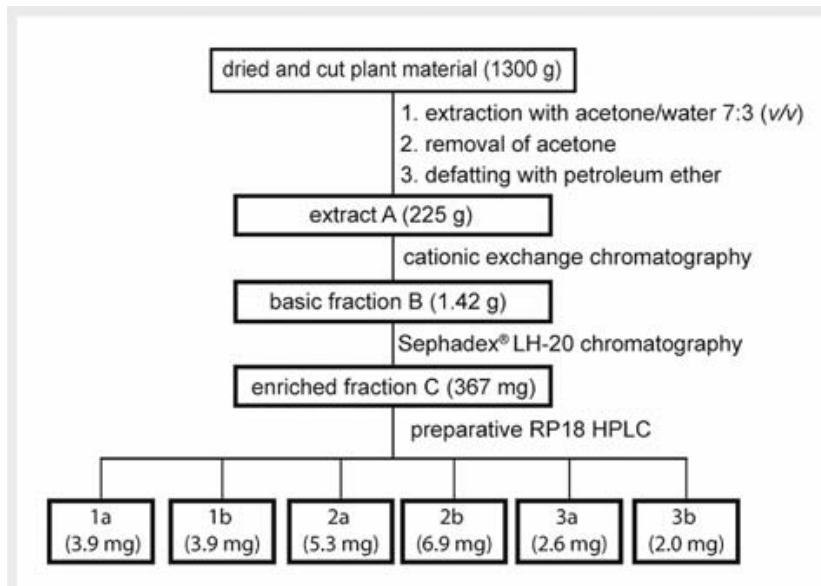

- Fig. 1 Fractionation scheme of dried lime flowers towards the isolation of 3,4-dihydro- $2 \mathrm{H}$-pyrrole alkaloids $1 \mathrm{a}$ and $1 \mathrm{~b}$, piperidine alkaloids $2 \mathrm{a}$ and $2 \mathrm{~b}$, and acetylated piperidine alkaloids $3 \mathrm{a}$ and $3 \mathrm{~b}$.

ously undescribed natural products, which were named as follows: tiliine $A(1 a)$ and tiliine $B(1 b)$, tiliamine $A(2 a)$ and tiliamine $B(2 b)$, and tilacetine $A(3 a)$ and tilacetine $B(3 b)$ ( $\bullet$ Fig. 2).

Compound $1 \mathrm{a}$ was isolated as a yellow oil from fraction $\mathrm{C}$. Detailed ${ }^{1} \mathrm{H},{ }^{13} \mathrm{C}, \mathrm{COSY}$, and NOESY NMR data of $1 \mathrm{a}$ are displayed in - Table 1. HR-MS analysis showed a quasi-molecular ion at $\mathrm{m} / \mathrm{z}$ $510.3081[\mathrm{M}+\mathrm{H}]^{+}$, correlating to the molecular formula $\left[\mathrm{C}_{27} \mathrm{H}_{44} \mathrm{NO}_{8}\right]^{+}$. MS 2 analysis at a collision energy of $70 \mathrm{eV}$ showed a fragment with $\mathrm{m} / \mathrm{z} 348.2491\left[\mathrm{C}_{21} \mathrm{H}_{34} \mathrm{NO}_{3}\right]^{+}$and a neutral loss of $162.0481 \mathrm{amu}\left(\mathrm{C}_{6} \mathrm{H}_{10} \mathrm{O}_{5}\right)$, indicating the presence of a hexose moiety (Fig. 2S, Supporting Information). This was also proven by carbohydrate-typical resonances in the respective NMR spectra (C-1"' to C-6"', see - Table 1 ). The UV spectrum showed a maximum of absorption at $\lambda_{\max } 285 \mathrm{~nm}$, indicating the presence of a phenolic group (Fig. 3aS, Supporting Information).

${ }^{13} \mathrm{C}$ NMR signals ( Table 1$)$ at $\delta_{\mathrm{C}} 153.5\left(\mathrm{C}-4^{\prime \prime}\right), 150.3\left(\mathrm{C}-1^{\prime \prime}\right)$, 135.1 (C-2"), 118.5 (C-6"), 117.4 (C-3"), and 113.84 (C-5") ppm indicated the presence of an aromatic system, in which 2 positions were linked to an oxygen (C-1", C-4") and 1 position was substituted by an additional carbon ( $\left.\mathrm{C}-2^{\prime \prime}\right)$. Para-substitution was deduced from the ${ }^{1} \mathrm{H}$ NMR signals at $\delta_{\mathrm{H}} 7.01 \mathrm{ppm}\left(\mathrm{H}-6^{\prime \prime}\right), \delta_{\mathrm{H}}$ $6.57 \mathrm{ppm}\left(\mathrm{H}-3^{\prime \prime}\right)$, and $\delta_{\mathrm{H}} 6.54 \mathrm{ppm}\left(\mathrm{H}-5^{\prime \prime}\right)$ and was additionally confirmed by the typical roof effect of the signals from $\mathrm{H}-5^{\prime \prime}$ and H-6" ( Table 1; Fig. 6aS, Supporting Information).

Interestingly, a carbon (C-5) with a strong downfield shift $\left(\delta_{C}\right.$ 195.08 ppm) was observed, which was assumed to be connected to a nitrogen atom via double bond linkage. HMBC data ( $\bullet$ Fig. 3; Fig. 6eS, Supporting Information) showed a correlation between the protons $\mathrm{H}-2, \mathrm{H}-4 \mathrm{a} / \mathrm{b}$, and $\mathrm{H}-3$ with $\mathrm{C}-5$. Together with the respective COSY NMR data ( $\triangleright$ Table 1) a 3,4-dihydro-2H-pyrrole structure was proposed. Additionally, substitution of the heterocycle by a methyl group was deduced, based on COSY correlations from $\mathrm{H}-2$ to the protons of a methyl group at $\delta_{\mathrm{H}} 1.42 \mathrm{ppm}(\mathrm{H}-6)$. Substitution of C-3 with a hydroxyl group was proposed on the basis of the typical downfield shift of $\mathrm{C}-3$ at $\delta_{\mathrm{C}} 64.0 \mathrm{ppm}$. Furthermore, HMBC data showed that an alkyl chain of 10 carbons 


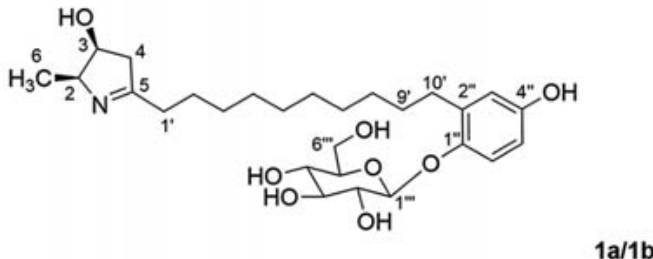

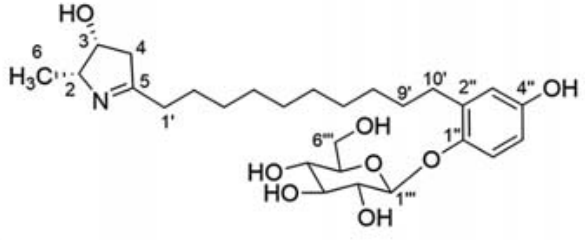

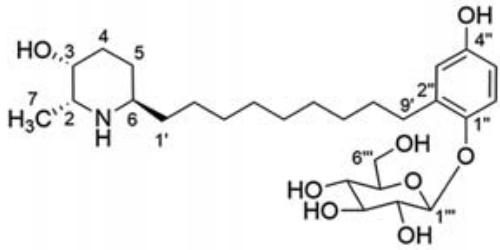

$2 \mathrm{a} / 2 \mathrm{~b}$

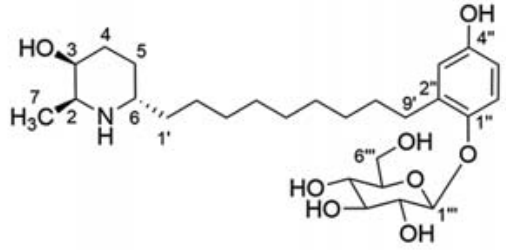

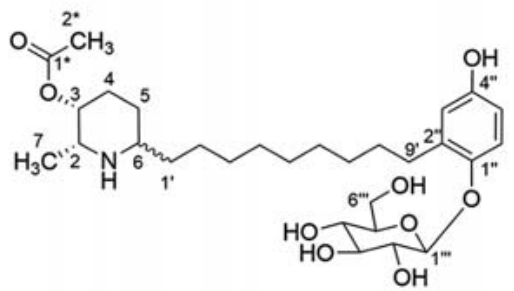

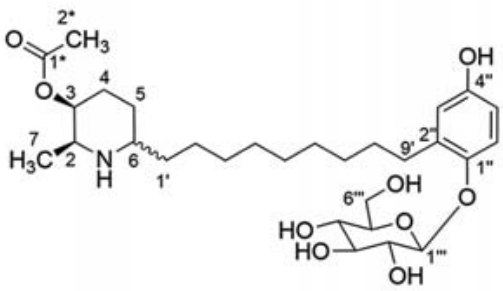

$3 a / 3 b$

- Fig. 2 Structures of 3,4-dihydro-2H-pyrrole alkaloids (1), piperidine alkaloids (2), and 3-O-acetylated piperidine alkaloids (3) from lime flower. As absolute stereochemistry at the $\mathrm{N}$-containing heterocycle has not been determined, both substituents at C-2/C-3 for $1 \mathrm{a}$ and $1 \mathrm{~b}$ resp. for C-2/C-3 for compounds $2 \mathrm{a}$ and $\mathbf{2 b}$ and $\mathbf{3 a}$ and $\mathbf{3 b}$ are cis-orientated and the existence of 2 diastereomers is obvious, but it cannot unambiguously notated which compound refers to which absolute stereochemistry. 1a/1b: tiline A/B, 2a/2b: tiliamine A/B, 3a/3b: tilacetine A/B.

(C-1'-C-10'), was linked to C-5 via C-1'. This alkyl chain connects the heterocycle with the phenolic part of the molecule, which was proven by HMBC correlations of the protons from carbon C-10' with the aromatic carbons ( $\vee$ Fig. 3; Fig. 6eS, Supporting Information).

Further analysis of the $\mathrm{MS}^{2}$ fragmentation pattern confirmed the proposed structural features. The different parts of the molecule (hexose, dihydroxy-methyl-phenol, alkyl chain, and methylhydroxy-disubstituted dihydropyrrole) were verified by the MS fragmentation pattern ( $\triangleright$ Fig. 4): after elimination of a hexose moiety, a neutral loss of 124.0519 amu was observed, indicative of a methyl-hydroquinone structure, as proposed by NMR analysis. The resulting fragment $\left(\mathrm{m} / \mathrm{z} 224.2011,\left[\mathrm{C}_{14} \mathrm{H}_{26} \mathrm{NO}\right]^{+}\right)$was in accordance with a methyl-hydroxy-disubstituted dihydropyrrole moiety linked to a 9-carbon alkyl chain. A series of neutral losses of 14.0166 amu $\left(\mathrm{CH}_{2}\right)$ was observable starting from $\mathrm{m} / \mathrm{z}$ 224.2011 and ending with the heterocyclic ring at $\mathrm{m} / \mathrm{z} 112.0756$ $\left[\mathrm{C}_{6} \mathrm{H}_{10} \mathrm{NO}\right]^{+}$. This confirms the proposed alkyl chain connected to a 2-methyl-3,4-dihydro-2H-pyrrol-3-ol moiety. Additionally, the elimination of the hydroxyl group in position $3(\Delta \mathrm{amu}=18)$ was observed at any stage of the fragmentation pathway.

At this point, the molecule was assumed to consist of 4 main structural elements: a 2-methyl-3,4-dihydro-2H-pyrrol-3-ol heterocycle, a C10 alkyl chain, a hydroquinone moiety, and a hexose residue. For clarification of the relative configuration at position $\mathrm{C}$ -
2 and C-3 of the heterocycle, NOESY experiments were performed, which showed a cross peak of $\mathrm{H}-2 / \mathrm{H}-3$. This indicated cis-configuration of the $\mathrm{H}-2 / \mathrm{H}-3$ protons ( $>$ Table 1 ; Fig. $6 \mathrm{fS}$, Supporting Information). Unfortunately, the elucidation of the absolute configuration by formation of distinct diastereomers using Mosher's acid chloride remained unsuccessful.

The sugar moiety proposed from NMR and HR-MS data of 1a was identified after acid hydrolysis of the Sephadex $\mathrm{LH}-20$ fraction C. TLC analysis against reference carbohydrates confirmed the presence of only glucose. The thin-layer chromatogram is shown in the Supporting Information, Fig. 4S. The absolute configuration of D-glucose was established after derivatization and separation of the diastereomers by CZE and comparison against the respective enantiomeric reference compounds [15]. The CZE electropherogram is displayed in the Supporting Information (Fig. 5S). The $\beta$-configuration of the glycosidic linkage at the anomeric center was verified by the ${ }^{13} \mathrm{C}$ signal of $\mathrm{C}-1^{\prime \prime \prime}$ at $\delta_{\mathrm{C}} 104.0 \mathrm{ppm}$, the corresponding ${ }^{1} \mathrm{H}$ signal at $\delta_{\mathrm{H}} 4.73 \mathrm{ppm}$, and the large coupling constant of $3 / \mathrm{H}-1^{\prime \prime \prime} / \mathrm{H}-2^{\prime \prime \prime}=7.8 \mathrm{~Hz}[16]$. From these investigations, the full structure of the 2-methyl-3,4-dihydro-2H-pyrrol-3-ol alkaloid 1 a (tiliine A) was established ( $\bullet$ Fig. 2), which is, to our best knowledge, a previously undescribed natural product.

Detailed ${ }^{1} \mathrm{H},{ }^{13} \mathrm{C}$, and COSY NMR data of $1 \mathrm{~b}$ are reported in - Table 1. Although compound 1b eluted in the analytical RP18UHPLC as a shoulder of the compound 1a peak (Fig. 1S, Support- 
- Table $1{ }^{1} \mathrm{H},{ }^{13} \mathrm{C}$, COSY, and NOESY spectroscopic data for compounds $1 \mathrm{a}$ and $1 \mathrm{~b}$.

\begin{tabular}{|c|c|c|c|c|c|c|c|c|}
\hline \multirow[b]{2}{*}{$\begin{array}{l}\text { Posi- } \\
\text { tion }\end{array}$} & \multicolumn{4}{|l|}{$1 \mathrm{a}$} & \multicolumn{4}{|l|}{$1 b$} \\
\hline & $\delta_{\mathrm{C}}[\mathrm{ppm}]$ & $\begin{array}{l}\delta_{\mathrm{H}}[\mathrm{ppm}] \text { (mult., } \\
J / \mathrm{Hz}, \text { No. H) }\end{array}$ & CosY & NOESY & $\delta_{\mathrm{C}}[\mathrm{ppm}]$ & $\begin{array}{l}\delta_{\mathrm{H}}[\mathrm{ppm}] \text { (mult., } \\
J / \mathrm{Hz}, \text { No. H) }\end{array}$ & $\cos Y$ & NOESY \\
\hline 2 & 57.2 & $3.86(\mathrm{~m}, 1 \mathrm{H})$ & $\mathrm{H}-3, \mathrm{H}-6$ & $\mathrm{H}-3, \mathrm{H}-4 \mathrm{a}, \mathrm{H}-6$ & 59.1 & $3.73(\mathrm{~m}, 1 \mathrm{H})$ & $\mathrm{H}-3, \mathrm{H}-6$ & $\mathrm{H}-3, \mathrm{H}-4 \mathrm{a}, \mathrm{H}-6$ \\
\hline 3 & 64.1 & $\begin{array}{l}4.04(\mathrm{dt}, J=4.8 \\
2.4 \mathrm{~Hz}, 1 \mathrm{H})\end{array}$ & $\begin{array}{l}\mathrm{H}-2, \\
\mathrm{H}-4 \mathrm{a} / \mathrm{b}\end{array}$ & $\mathrm{H}-2, \mathrm{H}-4 \mathrm{a} / \mathrm{b}, \mathrm{H}-6$ & 66.4 & $3.89(\mathrm{~m}, 1 \mathrm{H})$ & $\begin{array}{l}\mathrm{H}-2, \\
\mathrm{H}-4 \mathrm{a} / \mathrm{b}\end{array}$ & $\mathrm{H}-2, \mathrm{H}-4 \mathrm{a} / \mathrm{b}, \mathrm{H}-6$ \\
\hline $4 a$ & 25.4 & $1.92(\mathrm{~m}, 1 \mathrm{H})$ & $\mathrm{H}-3, \mathrm{H}-4 \mathrm{~b}$ & $\mathrm{H}-2, \mathrm{H}-3, \mathrm{H}-4 \mathrm{~b}$ & 22.5 & $\begin{array}{l}1.96(\mathrm{dd}, J=14.1 \\
2.6 \mathrm{~Hz}, 1 \mathrm{H})\end{array}$ & $\mathrm{H}-3, \mathrm{H}-4 \mathrm{~b}$ & $\mathrm{H}-2, \mathrm{H}-3, \mathrm{H}-4 \mathrm{~b}$ \\
\hline $4 \mathrm{~b}$ & & $\begin{array}{l}2.02(\mathrm{dd}, J=14.0, \\
4.2 \mathrm{~Hz}, 1 \mathrm{H})\end{array}$ & $\mathrm{H}-3, \mathrm{H}-4 \mathrm{a}$ & $\mathrm{H}-3, \mathrm{H}-4 \mathrm{~b}$ & & $\begin{array}{l}1.88(\mathrm{dd}, J=14.1 \\
6.2 \mathrm{~Hz}, 1 \mathrm{H})\end{array}$ & $\mathrm{H}-3, \mathrm{H}-4 \mathrm{a}$ & $\mathrm{H}-3, \mathrm{H}-4 \mathrm{~b}$ \\
\hline 5 & 195.1 & - & - & - & 193.0 & - & - & - \\
\hline 6 & 15.3 & $\begin{array}{l}1.42(\mathrm{~d}, J=7.0 \mathrm{~Hz} \\
3 \mathrm{H})\end{array}$ & $\mathrm{H}-2$ & $\mathrm{H}-2, \mathrm{H}-3$ & 15.3 & $\begin{array}{l}1.43(\mathrm{~d}, J=7.0 \mathrm{~Hz} \\
3 \mathrm{H})\end{array}$ & $\mathrm{H}-2$ & $\mathrm{H}-2, \mathrm{H}-3$ \\
\hline $1^{\prime}$ & 38.8 & $2.67(\mathrm{~m}, 2 \mathrm{H})$ & $\mathrm{H}-2^{\prime}$ & $\mathrm{H}-2^{\prime}, \mathrm{H}-3^{\prime}-8^{\prime}$ & 39.0 & $2.67(\mathrm{~m}, 2 \mathrm{H})$ & $\mathrm{H}-2^{\prime}$ & $\mathrm{H}-2^{\prime}, \mathrm{H}-3^{\prime}-8^{\prime}$ \\
\hline $2^{\prime}$ & 27.6 & $1.70(\mathrm{~m}, 2 \mathrm{H})$ & $\mathrm{H}-1^{\prime}, \mathrm{H}-3^{\prime}$ & $H-1^{\prime}, H-3^{\prime}-8^{\prime}$ & 27.2 & $\begin{array}{l}1.69(\mathrm{q}, J=7.3 \mathrm{~Hz}, \\
2 \mathrm{H})\end{array}$ & $\mathrm{H}-1^{\prime}, \mathrm{H}-3^{\prime}$ & $H-1^{\prime}, H-3^{\prime}-8^{\prime}$ \\
\hline $3^{\prime}-8^{\prime}$ & $30.01-30.4$ & $\begin{array}{l}1.35-1.29(\mathrm{~m}, \\
12 \mathrm{H})\end{array}$ & $\mathrm{H}-2^{\prime}, \mathrm{H}-9^{\prime}$ & $\begin{array}{l}\mathrm{H}-2^{\prime}, \mathrm{H}^{-} 9^{\prime}, \\
\mathrm{H}-10^{\prime} \mathrm{a} / \mathrm{b}, \mathrm{H}-3^{\prime \prime}\end{array}$ & $30.0-30.4$ & $\begin{array}{l}1.35-1.29 \\
(\mathrm{~m}, 12 \mathrm{H})\end{array}$ & $\mathrm{H}-2^{\prime}, \mathrm{H}-9^{\prime}$ & $\begin{array}{l}\mathrm{H}-2^{\prime}, \mathrm{H}-9^{\prime}, \\
\mathrm{H}-10^{\prime} \mathrm{a} / \mathrm{b}, \mathrm{H}-3^{\prime \prime}\end{array}$ \\
\hline $9^{\prime}$ & 31.2 & $\begin{array}{l}1.59(\mathrm{t}, J=7.3 \mathrm{~Hz} \\
2 \mathrm{H})\end{array}$ & $\begin{array}{l}\mathrm{H}-8^{\prime}, \\
\mathrm{H}-10^{\prime} \mathrm{a} / \mathrm{b}\end{array}$ & $\begin{array}{l}\mathrm{H}-2^{\prime}, \mathrm{H}-10^{\prime} \mathrm{a} / \mathrm{b}, \\
\mathrm{H}-3^{\prime \prime}\end{array}$ & 31.2 & $\begin{array}{l}1.59(\mathrm{t}, J=7.3 \mathrm{~Hz} \\
2 \mathrm{H})\end{array}$ & $\begin{array}{l}\mathrm{H}-8^{\prime}, \\
\mathrm{H}-10^{\prime} \mathrm{a} / \mathrm{b}\end{array}$ & $\begin{array}{l}\mathrm{H}-2^{\prime}, \mathrm{H}-10^{\prime} \mathrm{a} / \mathrm{b}, \\
\mathrm{H}-3^{\prime \prime}\end{array}$ \\
\hline $10^{\prime} \mathrm{a}$ & 31.0 & $\begin{array}{l}2.58(\mathrm{dt}, J=13.5 \\
7.6 \mathrm{~Hz}, 1 \mathrm{H})\end{array}$ & $\begin{array}{l}H-9^{\prime}, \\
H-10^{\prime} b\end{array}$ & $\begin{array}{l}\mathrm{H}-9^{\prime}, \mathrm{H}-10 \mathrm{~b}, \\
\mathrm{H}-3^{\prime \prime}\end{array}$ & 31.0 & $\begin{array}{l}2.59(\mathrm{dt}, J=13.3 \\
7.6 \mathrm{~Hz}, 1 \mathrm{H})\end{array}$ & $\begin{array}{l}H-9^{\prime}, \\
H-10^{\prime} b\end{array}$ & $\begin{array}{l}\text { H-9', H-10b, } \\
\text { H-3" }\end{array}$ \\
\hline $10^{\prime} b$ & & $2.68(\mathrm{~m}, 1 \mathrm{H})$ & $\begin{array}{l}\mathrm{H}-9^{\prime}, \\
\mathrm{H}-10^{\prime} \mathrm{a}\end{array}$ & $\begin{array}{l}\text { H-9', H-10a, } \\
\text { H-3" }\end{array}$ & & $2.68(\mathrm{~m}, 1 \mathrm{H})$ & $\begin{array}{l}\mathrm{H}-9^{\prime}, \\
\mathrm{H}-10^{\prime} \mathrm{a}\end{array}$ & $\begin{array}{l}\mathrm{H}-9^{\prime}, \mathrm{H}-10 \mathrm{a}, \\
\mathrm{H}-3^{\prime \prime}\end{array}$ \\
\hline $1^{\prime \prime}$ & 150.3 & - & - & - & 150.3 & - & - & - \\
\hline $2^{\prime \prime}$ & 135.1 & - & - & - & 135.1 & - & - & - \\
\hline $3^{\prime \prime}$ & 117.4 & $\begin{array}{l}6.57(\mathrm{~d}, J=3.0 \mathrm{~Hz} \\
1 \mathrm{H})\end{array}$ & $\mathrm{H}-5^{\prime \prime}$ & $\begin{array}{l}\mathrm{H}-3^{\prime}-8^{\prime}, \mathrm{H}-9^{\prime}, \\
\mathrm{H}-10^{\prime} \mathrm{a} / \mathrm{b}\end{array}$ & 117.4 & $\begin{array}{l}6.57(\mathrm{~d}, J=2.9 \mathrm{~Hz} \\
1 \mathrm{H})\end{array}$ & $\mathrm{H}-5^{\prime \prime}$ & $\begin{array}{l}\mathrm{H}-3^{\prime}-8^{\prime}, \mathrm{H}-9^{\prime}, \\
\mathrm{H}-10^{\prime} \mathrm{a} / \mathrm{b}\end{array}$ \\
\hline $4^{\prime \prime}$ & 153.5 & - & - & - & 153.5 & - & - & - \\
\hline $5^{\prime \prime}$ & 113.8 & $\begin{array}{l}6.54(\mathrm{dd}, J=8.6 \\
3.0 \mathrm{~Hz}, 1 \mathrm{H})\end{array}$ & $\mathrm{H}-6^{\prime \prime}$ & H-6" & 113.8 & $\begin{array}{l}6.55(\mathrm{dd}, J=8.6 \\
3.0 \mathrm{~Hz}, 1 \mathrm{H})\end{array}$ & H-6" & $\mathrm{H}-6^{\prime \prime}$ \\
\hline 6" & 118.5 & $\begin{array}{l}7.01(\mathrm{~d}, J=8.7 \mathrm{~Hz} \\
1 \mathrm{H})\end{array}$ & $\mathrm{H}-5^{\prime \prime}$ & $\mathrm{H}-5^{\prime \prime}, \mathrm{H}-1^{\prime \prime \prime}$ & 118.5 & $\begin{array}{l}7.01(\mathrm{~d}, J=8.7 \mathrm{~Hz} \\
1 \mathrm{H})\end{array}$ & $\mathrm{H}-5^{\prime \prime}$ & H-5", H-1"' \\
\hline $1^{\prime \prime \prime}$ & 104.0 & $\begin{array}{l}4.72(\mathrm{~d}, J=7.8 \mathrm{~Hz} \\
1 \mathrm{H})\end{array}$ & $\mathrm{H}-2^{\prime \prime \prime}$ & H-6", H-2"'-5"' & 104.0 & $\begin{array}{l}4.72(\mathrm{~d}, J=7.6 \mathrm{~Hz} \\
1 \mathrm{H})\end{array}$ & $\mathrm{H}-2^{\prime \prime \prime}$ & $\mathrm{H}-6^{\prime \prime}, \mathrm{H}-2^{\prime \prime \prime}-5^{\prime \prime \prime}$ \\
\hline $2^{\prime \prime \prime}$ & 75.2 & $3.43(\mathrm{~m}, 1 \mathrm{H})$ & $\mathrm{H}-1^{\prime \prime \prime}$ & $\mathrm{H}-1^{\prime \prime \prime}$ & 75.2 & $3.43(\mathrm{~m}, 1 \mathrm{H})$ & $\mathrm{H}-1^{\prime \prime \prime}$ & $\mathrm{H}-1^{\prime \prime \prime}$ \\
\hline $3^{\prime \prime \prime}$ & 78.4 & $3.43(\mathrm{~m}, 1 \mathrm{H})$ & $\mathrm{H}-4^{\prime \prime \prime}$ & $\mathrm{H}-1^{\prime \prime \prime}$ & 78.4 & $3.43(\mathrm{~m}, 1 \mathrm{H})$ & $\mathrm{H}-4^{\prime \prime \prime}$ & $\mathrm{H}-1^{\prime \prime \prime}$ \\
\hline $4^{\prime \prime \prime}$ & 71.5 & $3.37(\mathrm{~m}, 1 \mathrm{H})$ & $\mathrm{H}-3^{\prime \prime \prime}$ & $\mathrm{H}-1^{\prime \prime \prime}, \mathrm{H}-6^{\prime \prime \prime} \mathrm{a} / \mathrm{b}$ & 71.5 & $3.38(\mathrm{~m}, 1 \mathrm{H})$ & $\mathrm{H}-3^{\prime \prime \prime}$ & H-1"', H-6"'a/b \\
\hline $5^{\prime \prime \prime}$ & 78.0 & $3.37(\mathrm{~m}, 1 \mathrm{H})$ & $\mathrm{H}-6^{\prime \prime \prime}$ & $\mathrm{H}-1^{\prime \prime \prime}, \mathrm{H}-6^{\prime \prime \prime} \mathrm{a} / \mathrm{b}$ & 78.0 & $3.38(\mathrm{~m}, 1 \mathrm{H})$ & $\mathrm{H}-6^{\prime \prime \prime}$ & H-1"', H-6"'a/b \\
\hline 6"' a & 62.6 & $\begin{array}{l}3.70(\mathrm{dd}, J=12.0 \\
5.1 \mathrm{~Hz}, 1 \mathrm{H})\end{array}$ & $\begin{array}{l}\mathrm{H}-5^{\prime \prime \prime} \\
\mathrm{H}-6^{\prime \prime \prime} \mathrm{b}\end{array}$ & $H-6^{\prime \prime \prime} b$ & 62.6 & $3.71(\mathrm{~m}, 1 \mathrm{H})$ & $\begin{array}{l}\mathrm{H}-5^{\prime \prime \prime} \\
\mathrm{H}-6^{\prime \prime \prime} \mathrm{b}\end{array}$ & $\mathrm{H}-6^{\prime \prime \prime} \mathrm{b}$ \\
\hline 6"'b & & $\begin{array}{l}3.88(\mathrm{dd}, J=12.0, \\
2.1 \mathrm{~Hz}, 1 \mathrm{H})\end{array}$ & $\begin{array}{l}\text { H-5"', } \\
\text { H-6"'a }\end{array}$ & H-6"'a & & $3.88(\mathrm{~m}, 1 \mathrm{H})$ & $\begin{array}{l}\text { H-5"', } \\
\text { H-6"a }\end{array}$ & H-6"'a \\
\hline
\end{tabular}

ing Information), the peaks were sufficiently separated by preparative RP18-HPLC. The similar retention time of both peaks suggested structural similarity. This assumption was confirmed, as the UV spectrum ( $\lambda_{\max } 278 \mathrm{~nm}$ ), 1D and 2D NMR data, and HR-MS analysis showed the same structural features and molecular skeleton ( $\vee$ Table 1; Fig. 1S, 3bS, 7aS to 7fS, Supporting Information). Differences were only observed for the chemical shifts of $\mathrm{C}-2 / \mathrm{H}-2$ and $\mathrm{C}-3 / \mathrm{H}-3$ of the 2-methyl-3,4-dihydro- $2 \mathrm{H}$-pyrrol-3-ol hetero- cycle. This suggested a different configuration at these positions. NOESY correlations of $\mathrm{H}-2$ and $\mathrm{H}-3$ in compound $1 \mathrm{~b}$ were not clearly interpretable due to overlapping with the $\mathrm{H}-6^{\prime \prime \prime}$ signals of the sugar moiety. Thus, to determine the relative configuration, other correlations have to be taken into account. As observed in the NOESY spectrum of compound $1 \mathrm{a}$, the intensities of the cross peaks of $\mathrm{H}-3 / \mathrm{H}-4$ and $\mathrm{H}-3 / \mathrm{H}-6$ are comparable for the cis-configuration. In the case of a trans-configuration of $\mathrm{H}-2$ and $\mathrm{H}-3$, the 

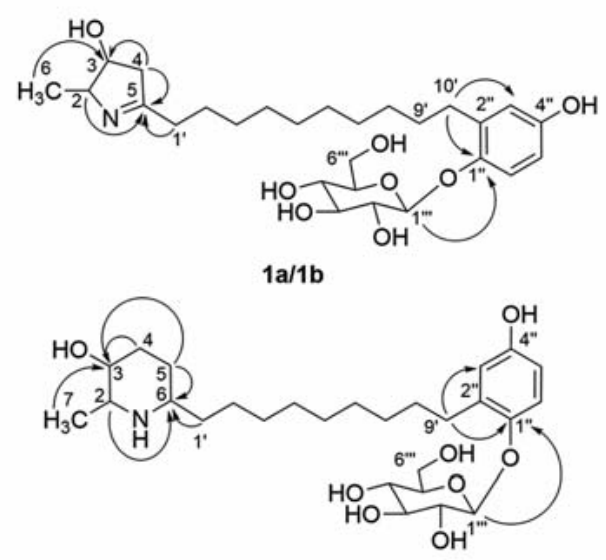

$2 \mathrm{a} / 2 \mathrm{~b}$

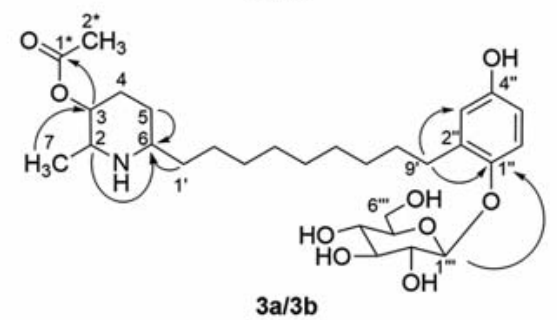

- Fig. 3 Key HMBC correlations for the 3 Tilia alkaloid classes, which are detectable for each of the respective stereoisomer. The arrows represent the correlations of a proton with the respective carbon.

protons of $\mathrm{H}-3$ and $\mathrm{H}-6$ would be closer and the intensity would be relatively higher compared with the signals of $\mathrm{H}-3$ with $\mathrm{H}-4$. This was not the case in the NOESY spectrum of compound $1 \mathrm{~b}$, where the intensities of the cross-peaks $\mathrm{H}-3 / \mathrm{H}-4$ and $\mathrm{H}-3 / \mathrm{H}-6$ were similar as well ( $\bullet$ Table $\mathbf{1}$; Fig. 7fS, Supporting Information). As all the other NOESY cross-peaks were analogue to those in compound 1a, compound $1 \mathrm{~b}$ was assumed to be a diastereomer of compound 1 a with cis-orientated C-2/C-3 substitution but with reversed absolute configuration (Fig. 7fS, Supporting Information). The elucidation of the absolute stereochemistry was unsuccessful.

To our knowledge, the structure of the 2-methyl-3,4-dihydro$2 \mathrm{H}$-pyrrol-3-ol alkaloid $1 \mathrm{~b}$ (tiliine $\mathrm{B})(\triangleright$ Fig. 1 ) has not been described until now for a natural product.

Compound 2a was isolated from a single peak during preparative HPLC of fraction C. HR-MS showed a quasi-molecular ion at $m / z 512.3223$, corresponding to the calculated molecular formula $\left[\mathrm{C}_{27} \mathrm{H}_{46} \mathrm{NO}_{8}\right]^{+}$. The mass difference to the molecular weight determined for compounds $1 \mathrm{a}$ and $1 \mathrm{~b}$ was $2.0142 \mathrm{amu}$, indicating 2 additional hydrogens in compound $2 \mathrm{a}$. The UV spectrum showed a maximum of absorption at $\lambda_{\max } 284 \mathrm{~nm}$, indicating the presence of a phenolic group (Fig. 3cS, Supporting Information). In $\mathrm{MS}^{2}$ spectrum, a neutral loss of 180.0651 amu was observed, representing a loss of a hexose moiety, followed by an elimination of $\mathrm{H}_{2} \mathrm{O}$. Detailed analysis of $1 \mathrm{D}$ and 2D NMR data revealed identical structural features as observed for compounds $1 \mathrm{a}$ and $1 \mathrm{~b}$ with regard to the $\beta$-linked hexose residue, which was determined by
CZE as D-glucose ( $\triangleright$ Table 2; Fig. 4 S and 5S, Supporting Information). The glucose moiety was again linked to a 1,4-hydroquinone moiety, substituted at C-2" by an alkyl chain. Structural differences got obvious in the NMR signals of the heterocyclic moiety. In contrast to compounds $1 \mathrm{a}$ and $1 \mathrm{~b}$, no downfield-shifted carbons were detectable. Instead, a ${ }^{13} \mathrm{C}$ signal at $\delta_{\mathrm{C}} 58.7 \mathrm{ppm}(\mathrm{C}-6)$ with 1 proton at $\delta_{\mathrm{H}} 3.06 \mathrm{ppm}(\mathrm{H}-6)$ was observed, indicating a $\mathrm{CH}$ group in direct neighborhood to the nitrogen atom. HMBC ( Fig. 3; Fig. 8 eS, Supporting Information) and COSY cross peaks ( $\vee$ Table 2; Fig. $8 \mathrm{fS}$, Supporting Information) revealed correlation to the alkyl chain on the one hand, and on the other hand, to a 6 membered heterocycle of 5 carbons and 1 nitrogen atom, which indicated a $\mathrm{C}$-2/C-3-disubstituted piperidine ring system. The positions $\mathrm{C}-2\left(\delta_{\mathrm{C}} 57.5 \mathrm{ppm}\right)$ and $\mathrm{C}-3\left(\delta_{\mathrm{C}} 65.8 \mathrm{ppm}\right)$ were assumed to be substituted with a methyl and a hydroxyl group, respectively. These structural elements could also be verified by MS² fragmentation analysis ( $\bullet$ Fig. 5), which showed after the loss of the hexose moiety and the elimination of $\mathrm{H}_{2} \mathrm{O}$, a loss of a dihydroxymethyl-phenyl moiety ( $\Delta=124.0506 \mathrm{amu})$. This resulted in a hydroxyl-methyl-disubstituted alkyl-piperidine ring system, again eliminating alkyl residues toward the final fragment of $\left[\mathrm{C}_{6} \mathrm{H}_{10} \mathrm{~N}\right]^{+}$, which was in accordance with a double unsaturated methyl-piperidine ring. For clarification of the relative configuration at C-2 and C-3 of the heterocycle, NOESY experiments were performed, which clearly indicated cis-configuration of the $\mathrm{H}-2 / \mathrm{H}-3$ protons ( $\triangleright$ Table 2; Fig. 8fS, Supporting Information). No NOESY cross peak was observed between the $\mathrm{H}-2 / \mathrm{H}-3$ protons and the $\mathrm{H}-6$ proton, indicating that the $\mathrm{H}-6$ proton is on the opposite side (trans) of the heterocycle. The elucidation of the absolute configuration was not successful.

From these investigations, the structure of the piperidine alkaloid 2a (tiliamine A) can be deduced ( $\bullet$ Fig. 1), a previously undescribed natural product.

Compound $2 \mathrm{~b}$ eluted during preparative HPLC directly after compound 2a. As the HR-MS of this compound had the same mass ( $m / z$ 512.3233) as compound 2a, structural similarities have to be assumed, which was confirmed by the identical MS ${ }^{2}$ fragmentation pattern ( $\bullet$ Fig. 5) and UV spectrum $\left(\lambda_{\max } 285 \mathrm{~nm}\right)$ (Fig. 2S, 3dS, Supporting Information). Examination of the NMR data showed identical signals for the hexose moiety, the hydroquinone moiety, and the alkyl chain, whereas differences were apparent for the heterocycle, indicating a different configuration at positions C-2, C-3, and C-6 compared to compound 2a ( $\bullet$ Table 2 ). NOESY correlations of $2 b$ were identical to those obtained for $2 \mathrm{a}$, which led to the conclusion that compound $2 \mathrm{~b}$ should be a diastereomer of compound 2a with cis-orientated protons at C-2, C-3 and C-6 but with reversed absolute configuration ( $>$ Table 2; Fig. 9fS, Supporting Information). The elucidation of the absolute stereochemistry was not successful.

From these investigations, the structure of the piperidine alkaloid 2 b (tiliamine B) can be deduced ( $\bullet$ Fig. 1), which is, to our best knowledge, a previously undescribed natural product.

Compound $3 \mathrm{a}$ eluted after compounds $2 \mathrm{a}$ and $\mathbf{2 b}$ on preparative RP18-HPLC, which indicated a more lipophilic character of 3a as compared to the previous compounds. LC-HR-MS analysis showed a quasi-molecular ion at $\mathrm{m} / \mathrm{z} 554.3378$, which corresponded to the molecular formula $\left[\mathrm{C}_{29} \mathrm{H}_{48} \mathrm{NO}_{9}\right]^{+}$. The UV spec- 


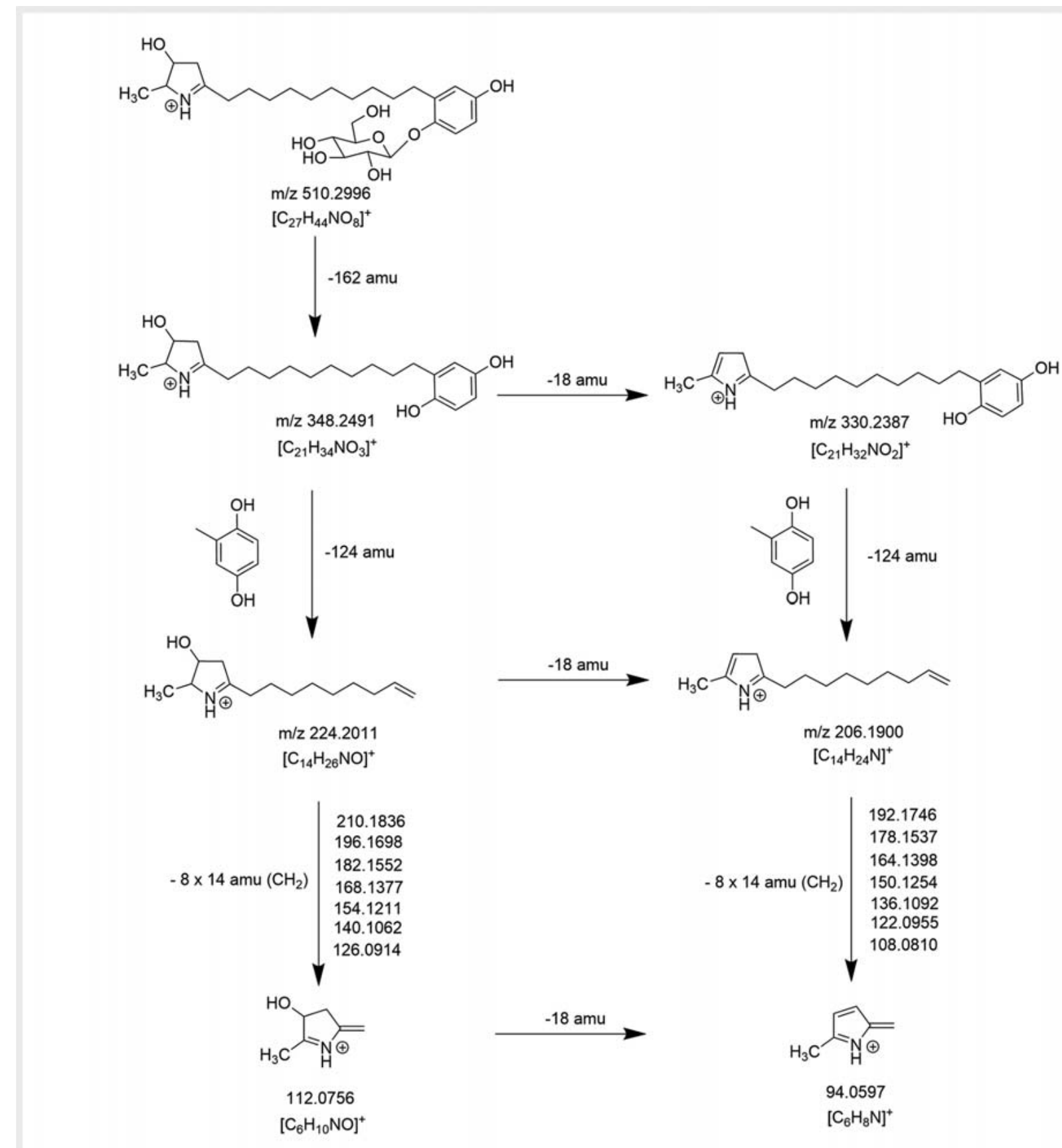

- Fig. 4 Proposed $\mathrm{MS}^{2}$ fragmentation sequence of 3,4-dihydro-2H-pyrrole alkaloids tilliines A and B from lime flowers.

trum showed an absorption maximum at $\lambda_{\max } 285 \mathrm{~nm}$ (Fig. 3eS, Supporting Information). The mass difference of 42.0115 amu compared to compound 2 a could be explained by an additional acetyl group. Analysis of 1D and 2D NMR data again revealed strong similarities to the above described compounds regarding the existence of a $\beta$-linked hexose residue, a 2 -alkyl hydroquinone moiety, and an alkyl chain. Also, similar signals were observed for the 2-methyl-piperidin-3-ol ring, but in contrast to compounds 2 a and $2 b$, a downfield shift of the proton and the carbon at position C-3 was observed, suggesting an acetyl group at the C-3 hydroxyl group. Furthermore, in the ${ }^{13} \mathrm{C}$ NMR spectrum, additional signals at $\delta_{C} 171.3$ and $20.7 \mathrm{ppm}$ confirmed the presence of an acetyl group. The correlation of $\mathrm{H}-3$ with the carbonyl-carbon at $\delta_{C}$ 171.3 in the HMBC spectrum ( $\vee$ Fig. 3; Fig. 10eS, Supporting Information) confirmed the acetylation of the C-3 hydroxyl group. In contrast to compounds $2 \mathrm{a}$ and $2 \mathrm{~b}$, the NOESY spectrum of compound 3 a revealed the correlations of $\mathrm{H}-2, \mathrm{H}-3$, and $\mathrm{H}-6$, indicating cis-configuration of all piperidine (C-2, C-3, and C-6) substituents ( $\triangleright$ Table 3; Fig. 10fS, Supporting Information). The elucidation of the absolute stereochemistry was not successful. 
- Table $2{ }^{1} \mathrm{H},{ }^{13} \mathrm{C}, \mathrm{COSY}$ and NOESY spectroscopic data for compounds $2 \mathrm{a}$ and $2 \mathrm{~b}$.

\begin{tabular}{|c|c|c|c|c|c|c|c|c|}
\hline \multirow[b]{2}{*}{$\begin{array}{l}\text { Posi- } \\
\text { tion }\end{array}$} & \multicolumn{4}{|l|}{$2 a$} & \multicolumn{4}{|l|}{$2 b$} \\
\hline & $\delta_{\mathrm{C}}[\mathrm{ppm}]$ & $\begin{array}{l}\delta_{\mathrm{H}}[\mathrm{ppm}] \text { (mult., } \\
J / \mathrm{Hz}, \text { No. H) }\end{array}$ & cosY & NOESY & $\delta_{\mathrm{C}}[\mathrm{ppm}]$ & $\begin{array}{l}\delta_{\mathrm{H}}[\mathrm{ppm}] \text { (mult., } \\
J / \mathrm{Hz}, \text { No. H) }\end{array}$ & $\cos Y$ & NOESY \\
\hline 2 & 57.5 & $3.23(\mathrm{~m}, 1 \mathrm{H})$ & $\mathrm{H}-3, \mathrm{H}-7$ & $\mathrm{H}-3, \mathrm{H}-4 \mathrm{a}, \mathrm{H}-7$ & 52.0 & $\begin{array}{l}3.47(\mathrm{dd}, J=6.7, \\
2.7 \mathrm{~Hz}, 1 \mathrm{H})\end{array}$ & $\mathrm{H}-3, \mathrm{H}-7$ & $\begin{array}{l}\mathrm{H}-3, \mathrm{H}-4 \mathrm{~b}, \mathrm{H}-7, \\
\mathrm{H}^{-1} \mathrm{\prime} \mathrm{a} / \mathrm{b}\end{array}$ \\
\hline 3 & 65.8 & $\begin{array}{l}3.84(\mathrm{dt}, J=3.4,1.6 \mathrm{~Hz}, \\
1 \mathrm{H})\end{array}$ & $\mathrm{H}-2, \mathrm{H}-4 \mathrm{a} / \mathrm{b}$ & $\begin{array}{l}\mathrm{H}-2, \mathrm{H}-4 \mathrm{a} / \mathrm{b} \\
\mathrm{H}-7\end{array}$ & 66.4 & $\begin{array}{l}3.84(\mathrm{dt}, J=5.9,2.9 \mathrm{~Hz} \\
1 \mathrm{H})\end{array}$ & $\mathrm{H}-2, \mathrm{H}-4 \mathrm{a} / \mathrm{b}$ & $\begin{array}{l}\mathrm{H}-2, \mathrm{H}-4 \mathrm{a} / \mathrm{b} \\
\mathrm{H}-5 \mathrm{a}, \mathrm{H}-7\end{array}$ \\
\hline $4 a$ & 31.0 & $1.72(\mathrm{~m}, 1 \mathrm{H})$ & $\begin{array}{l}\mathrm{H}-3, \mathrm{H}-4 \mathrm{~b}, \\
\mathrm{H}-5 \mathrm{a} / \mathrm{b}\end{array}$ & $\begin{array}{l}\mathrm{H}-3, \mathrm{H}-4 \mathrm{~b}, \\
\mathrm{H}-5 \mathrm{a} / \mathrm{b}\end{array}$ & 26.2 & $1.77(\mathrm{~m}, 1 \mathrm{H})$ & $\begin{array}{l}\mathrm{H}-3, \mathrm{H}-4 \mathrm{~b}, \\
\mathrm{H}-5 \mathrm{a} / \mathrm{b}\end{array}$ & $\begin{array}{l}\mathrm{H}-3, \mathrm{H}-4 \mathrm{~b}, \mathrm{H}-5 \mathrm{~b}, \\
\mathrm{H}-7\end{array}$ \\
\hline $4 b$ & & $1.96(\mathrm{~m}, 1 \mathrm{H})$ & $\begin{array}{l}\mathrm{H}-3, \mathrm{H}-4 \mathrm{a} \\
\mathrm{H}-5 \mathrm{a} / \mathrm{b}\end{array}$ & $\mathrm{H}-3, \mathrm{H}-4 \mathrm{a}, \mathrm{H}-5 \mathrm{a}$ & & $\begin{array}{l}1.86(\mathrm{ddt}, J=14.1 \\
10.6,3.7 \mathrm{~Hz}, 1 \mathrm{H})\end{array}$ & $\begin{array}{l}\mathrm{H}-3, \mathrm{H}-4 \mathrm{a} \\
\mathrm{H}-5 \mathrm{a} / \mathrm{b}\end{array}$ & $\begin{array}{l}\mathrm{H}-2, \mathrm{H}-3, \mathrm{H}-4 \mathrm{a}, \\
\mathrm{H}-5 \mathrm{a}\end{array}$ \\
\hline $5 a$ & 23.6 & $1.72(\mathrm{~m}, 1 \mathrm{H})$ & $\begin{array}{l}\mathrm{H}-4, \mathrm{H}-5 \mathrm{~b}, \\
\mathrm{H}-6\end{array}$ & $\begin{array}{l}\mathrm{H}-4 \mathrm{~b}, \mathrm{H}-5 \mathrm{~b}, \\
\mathrm{H}-6\end{array}$ & 22.2 & $1.57(\mathrm{~m}, 1 \mathrm{H})$ & $\begin{array}{l}\mathrm{H}-4, \mathrm{H}-5 \mathrm{~b} \\
\mathrm{H}-6\end{array}$ & $\begin{array}{l}\mathrm{H}-3, \mathrm{H}-6, \mathrm{H}-4 \mathrm{~b}, \\
\mathrm{H}-5 \mathrm{~b},\end{array}$ \\
\hline $5 b$ & & $1.82(\mathrm{~m}, 1 \mathrm{H})$ & $\begin{array}{l}\mathrm{H}-4, \mathrm{H}-5 \mathrm{a}, \\
\mathrm{H}-6\end{array}$ & $\mathrm{H}-4 \mathrm{a}, \mathrm{H}-5 \mathrm{a}, \mathrm{H}-6$ & & $\begin{array}{l}2.14(\mathrm{ddt}, J=14.8 \\
10.4,4.4 \mathrm{~Hz}, 1 \mathrm{H})\end{array}$ & $\begin{array}{l}\mathrm{H}-4, \mathrm{H}-5 \mathrm{a}, \\
\mathrm{H}-6\end{array}$ & H6-, H-4a, H-5a \\
\hline 6 & 58.7 & $\begin{array}{l}3.06(\mathrm{tdd}, J=11.7,8.5 \\
4.2 \mathrm{~Hz}, 1 \mathrm{H})\end{array}$ & $\mathrm{H}-5 \mathrm{a} / \mathrm{b}, \mathrm{H}-\mathbf{1}^{\prime}$ & $\begin{array}{l}\mathrm{H}-5 \mathrm{a} / \mathrm{b}, \\
\mathrm{H}-1^{\prime} \mathrm{a} / \mathrm{b}, \\
\mathrm{H}-3^{\prime}-7^{\prime}\end{array}$ & 53.6 & $3.34(\mathrm{~m}, 1 \mathrm{H})$ & $\mathrm{H}-5 \mathrm{a} / \mathrm{b}, \mathrm{H}-\mathbf{1}^{\prime}$ & $\begin{array}{l}\mathrm{H}-5 \mathrm{a} / \mathrm{b}, \mathrm{H}-7, \\
\mathrm{H}-1^{\prime} \mathrm{a} / \mathrm{b}, \mathrm{H}-3^{\prime}-7^{\prime}\end{array}$ \\
\hline 7 & 15.9 & $1.33(\mathrm{~m}, 3 \mathrm{H})$ & $\mathrm{H}-2$ & $\mathrm{H}-2, \mathrm{H}-3$ & 13.8 & $1.31(\mathrm{~m}, 3 \mathrm{H})$ & $\mathrm{H}-2$ & $\begin{array}{l}\mathrm{H}-2, \mathrm{H}-3, \mathrm{H}-4 \mathrm{a}, \\
\mathrm{H}-6\end{array}$ \\
\hline 1'a & 34.7 & $1.57(\mathrm{~m}, 1 \mathrm{H})$ & $\mathrm{H}-1^{\prime} \mathrm{b}, \mathrm{H}-2^{\prime}$ & $\mathrm{H}-1^{\prime} \mathrm{b}$ & 30.4 & $\begin{array}{l}1.65(\mathrm{dt}, J=8.8,4.5 \mathrm{~Hz}, \\
1 \mathrm{H})\end{array}$ & $\mathrm{H}-1^{\prime} \mathrm{b}, \mathrm{H}-\mathrm{2}^{\prime}$ & $\mathrm{H}-2, \mathrm{H}-6, \mathrm{H}-1^{\prime} \mathrm{b}$ \\
\hline $1^{\prime} b$ & & $1.67(\mathrm{~m}, 1 \mathrm{H})$ & $\mathrm{H}-1^{\prime} \mathrm{a}, \mathrm{H}-2^{\prime}$ & H-1'a & & $1.78(\mathrm{~m}, 1 \mathrm{H})$ & $\mathrm{H}-1^{\prime} \mathrm{a}, \mathrm{H}-2^{\prime}$ & H-2, H-6, H-1'a \\
\hline $2^{\prime} \mathrm{a}$ & 26.3 & $\begin{array}{l}1.44(\mathrm{ddd}, J=10.3,5.8, \\
2.6 \mathrm{~Hz}, 1 \mathrm{H})\end{array}$ & $\begin{array}{l}H-1^{\prime}, H-2^{\prime} b, \\
H-3^{\prime}\end{array}$ & n. o. & 27.0 & $1.40(\mathrm{~m}, 1 \mathrm{H})$ & $\begin{array}{l}H-1^{\prime}, H-2^{\prime} b \\
H-3^{\prime}\end{array}$ & $\mathrm{H}-1^{\prime} \mathrm{a} / \mathrm{b}$ \\
\hline $2^{\prime} b$ & & $1.37(\mathrm{~m}, 1 \mathrm{H})$ & $\begin{array}{l}\mathrm{H}-1^{\prime}, \mathrm{H}-2^{\prime} \mathrm{a}, \\
\mathrm{H}-3^{\prime}\end{array}$ & n.o. & & $1.44(\mathrm{~m}, 1 \mathrm{H})$ & $\begin{array}{l}\mathrm{H}-1^{\prime}, \mathrm{H}-2^{\prime} \mathrm{a} \\
\mathrm{H}-3^{\prime}\end{array}$ & $\mathrm{H}-1$ 'a/b \\
\hline $3^{\prime}-7^{\prime}$ & $30.4-30.5$ & $1.35-1.37(\mathrm{~m}, 10 \mathrm{H})$ & $\mathrm{H}-2^{\prime} \mathrm{a} / \mathrm{b}, \mathrm{H}-8^{\prime}$ & $\begin{array}{l}\text { H-8', H-9'a/b, } \\
\text { H-6 }\end{array}$ & $30.4-30.5$ & $1.32-1.37(\mathrm{~m}, 10 \mathrm{H})$ & $\begin{array}{l}\mathrm{H}-2^{\prime} \mathrm{a} / \mathrm{b}, \\
\mathrm{H}-8^{\prime}\end{array}$ & $\begin{array}{l}\text { H-1'a/b, H-8', } \\
\text { H-9'a/b, H-6 }\end{array}$ \\
\hline $8^{\prime}$ & 31.3 & $1.59(\mathrm{~m}, 2 \mathrm{H})$ & H-7', H-9'a/b & $\begin{array}{l}\text { H-3'-7', } \\
\text { H-9'a/b, H-3" }\end{array}$ & 31.3 & $1.59(\mathrm{t}, J=7.2 \mathrm{~Hz}, 2 \mathrm{H})$ & $\begin{array}{l}\text { H-7', } \\
\text { H-9'a/b }\end{array}$ & $\begin{array}{l}H-3^{\prime}-7^{\prime}, H-9^{\prime} a / b, \\
H-3^{\prime \prime}\end{array}$ \\
\hline 9'a & 31.0 & $\begin{array}{l}2.59(\mathrm{dt}, J=13.4, \\
7.7 \mathrm{~Hz}, 1 \mathrm{H})\end{array}$ & $H-8^{\prime}, H-9^{\prime} b$ & $\begin{array}{l}H-8^{\prime}, H-9^{\prime} b, \\
H-3^{\prime \prime}\end{array}$ & 31.0 & $\begin{array}{l}2.59(\mathrm{dt}, J=13.4 \\
7.7 \mathrm{~Hz}, 1 \mathrm{H})\end{array}$ & $H-8^{\prime}, H-9^{\prime} b$ & $H-8^{\prime}, H-9^{\prime} b, H-3^{\prime \prime}$ \\
\hline $9 \prime b$ & & $2.69(\mathrm{~m}, 1 \mathrm{H})$ & $\mathrm{H}-8^{\prime}, \mathrm{H}-9^{\prime} \mathrm{a}$ & $\begin{array}{l}\text { H-8', H-9'a, } \\
\text { H-3" }\end{array}$ & & $\begin{array}{l}2.69(\mathrm{dt}, J=13.5, \\
7.6 \mathrm{~Hz}, 1 \mathrm{H})\end{array}$ & H-8', H-9'a & H-8', H-9'a, H-3" \\
\hline $1^{\prime \prime}$ & 150.3 & - & - & - & 150.3 & - & - & - \\
\hline $2^{\prime \prime}$ & 135.2 & - & - & - & 135.1 & - & - & - \\
\hline $3^{\prime \prime}$ & 117.3 & $6.57(\mathrm{~d}, J=3.0 \mathrm{~Hz}, 1 \mathrm{H})$ & $\mathrm{H}-5^{\prime \prime}$ & $\begin{array}{l}\text { H-3'-7', H-8', } \\
\text { H-9'a/b }\end{array}$ & 117.3 & $6.57(\mathrm{~d}, J=3.0 \mathrm{~Hz}, 1 \mathrm{H})$ & $\mathrm{H}-5^{\prime \prime}$ & $\begin{array}{l}\text { H-3'-7', H-8', } \\
\text { H-9'a/b }\end{array}$ \\
\hline $4^{\prime \prime}$ & 153.5 & - & - & - & 153.5 & - & - & - \\
\hline $5^{\prime \prime}$ & 113.8 & $\begin{array}{l}6.55(\mathrm{dd}, J=8.7, \\
3.0 \mathrm{~Hz}, 1 \mathrm{H})\end{array}$ & $\mathrm{H}-6^{\prime \prime}$ & H-6" & 113.8 & $\begin{array}{l}6.55(\mathrm{dd}, J=8.7, \\
3.0 \mathrm{~Hz}, 1 \mathrm{H})\end{array}$ & $H-6^{\prime \prime}$ & $\mathrm{H}-6^{\prime \prime}$ \\
\hline 6" & 118.5 & $7.01(\mathrm{~d}, J=8.7 \mathrm{~Hz}, 1 \mathrm{H})$ & $\mathrm{H}-5^{\prime \prime}$ & $\mathrm{H}-5^{\prime \prime}, \mathrm{H}-1^{\prime \prime \prime}$ & 118.5 & $7.01(\mathrm{~d}, J=8.7 \mathrm{~Hz}, 1 \mathrm{H})$ & $\mathrm{H}-5^{\prime \prime}$ & $\mathrm{H}-5^{\prime \prime}, \mathrm{H}-1^{\prime \prime \prime}$ \\
\hline $1^{\prime \prime \prime}$ & 104.0 & $4.73(\mathrm{~d}, J=7.7 \mathrm{~Hz}, 1 \mathrm{H})$ & $\mathrm{H}-2^{\prime \prime \prime}$ & H-6", H-2"'-5"' & 104.0 & $4.73(\mathrm{~d}, J=7.2 \mathrm{~Hz}, 1 \mathrm{H})$ & $\mathrm{H}-2^{\prime \prime \prime}$ & $H-6^{\prime \prime}, H-2^{\prime \prime \prime}-5^{\prime \prime \prime}$ \\
\hline $2^{\prime \prime \prime}$ & 75.2 & $3.43(\mathrm{~m}, 1 \mathrm{H})$ & $\mathrm{H}-1^{\prime \prime \prime}$ & $\mathrm{H}-1^{\prime \prime \prime}$ & 75.2 & $3.45(\mathrm{~m}, 1 \mathrm{H})$ & $\mathrm{H}-1^{\prime \prime \prime}$ & $\mathrm{H}-1^{\prime \prime \prime}$ \\
\hline $3^{\prime \prime \prime}$ & 78.4 & $3.43(\mathrm{~m}, 1 \mathrm{H})$ & $\mathrm{H}-4^{\prime \prime \prime}$ & $\mathrm{H}-1^{\prime \prime \prime}$ & 78.4 & $3.45(\mathrm{~m}, 1 \mathrm{H})$ & $\mathrm{H}-4^{\prime \prime \prime}$ & $\mathrm{H}-1^{\prime \prime \prime}$ \\
\hline $4^{\prime \prime \prime}$ & 71.5 & $3.37(\mathrm{~m}, 1 \mathrm{H})$ & $\mathrm{H}-3^{\prime \prime \prime}$ & H-1"', H-6"'a/b & 71.5 & $3.37(\mathrm{~m}, 1 \mathrm{H})$ & $\mathrm{H}-3^{\prime \prime \prime}$ & H-1"', H-6"'a/b \\
\hline $5^{\prime \prime \prime}$ & 78.0 & $3.37(\mathrm{~m}, 1 \mathrm{H})$ & $\mathrm{H}-6^{\prime \prime \prime}$ & H-1"', H-6"'a/b & 78.0 & $3.37(\mathrm{~m}, 1 \mathrm{H})$ & $\mathrm{H}-6^{\prime \prime \prime}$ & H-1"', H-6"'a/b \\
\hline 6"'a & 62.6 & $\begin{array}{l}3.70(\mathrm{dd}, J=12.0, \\
5.2 \mathrm{~Hz}, 1 \mathrm{H})\end{array}$ & $\begin{array}{l}\text { H-5"', } \\
\text { H-6"'b }\end{array}$ & $H-6^{\prime \prime \prime} b$ & 62.7 & $\begin{array}{l}3.71(\mathrm{dd}, J=12.0, \\
5.2 \mathrm{~Hz}, 1 \mathrm{H})\end{array}$ & $\mathrm{H}-5^{\prime \prime \prime}, \mathrm{H}-6^{\prime \prime \prime} \mathrm{b}$ & $H-6^{\prime \prime \prime} b$ \\
\hline 6"'b & & $\begin{array}{l}3.88(\mathrm{dd}, J=12.0, \\
2.1 \mathrm{~Hz}, 1 \mathrm{H})\end{array}$ & $\begin{array}{l}\text { H-5"', } \\
\text { H-6"'a }\end{array}$ & H-6"'a & & $\begin{array}{l}3.89(\mathrm{dd}, J=12.0, \\
2.1 \mathrm{~Hz}, 1 \mathrm{H})\end{array}$ & H-5"', H-6"'a & H-6"'a \\
\hline
\end{tabular}




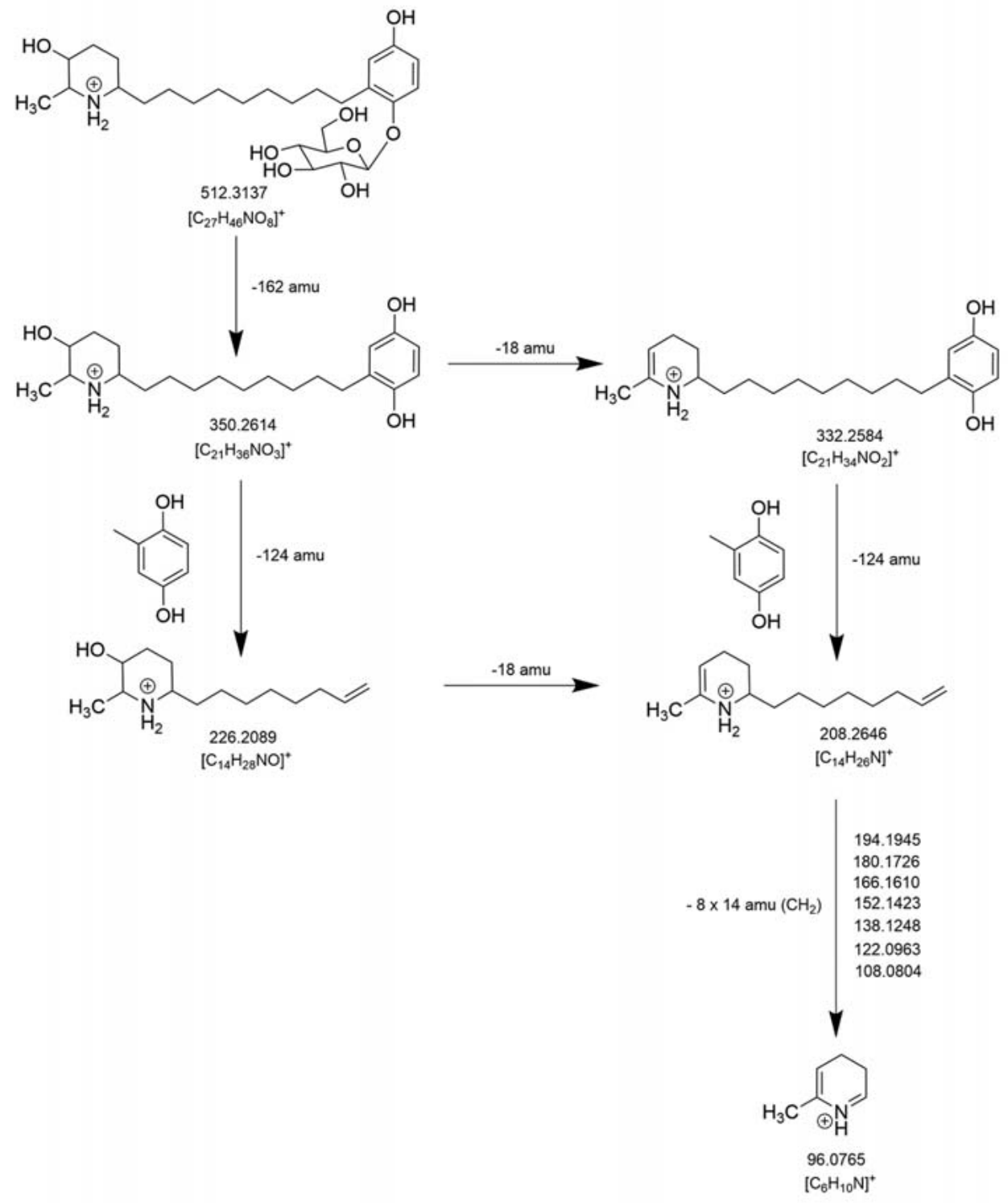

- Fig. 5 Proposed $\mathrm{MS}^{2}$ fragmentation sequence of piperidine alkaloids tiliamines A and B from lime flowers.

The MS fragmentation pattern of compound 3a was very similar to the pattern of the non-acetylated compounds $2 \mathrm{a}$ and $2 \mathrm{~b}$, as esterified hydroxyl groups are typically eliminated under formation of a double bond $(\Delta a m u=60)$. As the only difference, ions indicative of the respective hydroxylated fragments were absent.

From these investigations, the structure of the 3-O acetylatedpiperidine alkaloid 3a (tilacetine A) was deduced ( $\bullet$ Fig. 1), which is, to our best knowledge, a previously undescribed natural product.

Compound 3b eluted after compound 3a on preparative RP18HPLC and exhibited the same $m / z 554.3382[\mathrm{M}+\mathrm{H}]^{+}$, UV $\left(\lambda_{\max }\right.$ $285 \mathrm{~nm}), 1 \mathrm{D}$ and 2D NMR data, as well as MS fragmentation pattern. Differences were observed with regard to the relative configuration. In the NOESY spectrum, a cross peak between $\mathrm{H}-2$ and $\mathrm{H}$ 3 was visible, but a correlation with $\mathrm{H}-6$ was absent. This indicated a cis-configuration of substituents at C-2 and C-3 as observed for compounds $2 \mathrm{a}$ and $2 \mathrm{~b}$ ( $\triangleright$ Table 3; Fig. 11fS, Supporting Information). The elucidation of the absolute configuration was not successful. The HMBC and NOESY correlations between the acetyl group with the heterocycle were missing, probably because of the lower amount of compound 3b. However, the downfield shift of the proton and carbon at position 3 unambiguously indicated that this position was acetylated in this compound as well.

These data established the structure of the 3-O acetylated-piperidine alkaloid $3 \mathrm{~b}$ (tilacetine B) ( $\bullet$ Fig. 1), which is, to our best knowledge, a previously undescribed natural product.

LC-HR-MS 2 analysis of fraction $C$ indicated the existence of a further alkaloid with $\mathrm{m} / \mathrm{z}$ of 552.3230 , which could have structural similarity to acetyl-tiliine (Figs. S1 and S2, Supporting Information). The exact structure could not be established by detailed 
- Table $3{ }^{1} \mathrm{H},{ }^{13} \mathrm{C}$, COSY, and NOESY spectroscopic data for compounds 3a and 3b.

\begin{tabular}{|c|c|c|c|c|c|c|c|c|}
\hline \multirow[b]{2}{*}{$\begin{array}{l}\text { Posi- } \\
\text { tion }\end{array}$} & \multicolumn{4}{|l|}{$3 a$} & \multicolumn{4}{|l|}{$3 b$} \\
\hline & $\delta_{\mathrm{C}}[\mathrm{ppm}]$ & $\begin{array}{l}\delta_{\mathrm{H}}[\mathrm{ppm}] \text { (mult., } \\
J / \mathrm{Hz}, \text { No. } \mathrm{H})\end{array}$ & COSY & NOESY & $\delta_{\mathrm{C}}[\mathrm{ppm}]$ & $\begin{array}{l}\delta_{\mathrm{H}}[\mathrm{ppm}] \text { (mult., } \\
J / \mathrm{Hz}, \text { No. H) }\end{array}$ & cosY & NOESY \\
\hline 2 & 55.8 & $\begin{array}{l}3.50(\mathrm{qd}, J=6.7, \\
2.0 \mathrm{~Hz}, 1 \mathrm{H})\end{array}$ & $\mathrm{H}-3, \mathrm{H}-7$ & $\begin{array}{l}\mathrm{H}-3, \mathrm{H}-4 \mathrm{a} \\
\mathrm{H}-6, \mathrm{H}-7\end{array}$ & 50.1 & $3.74(\mathrm{~m}, 1 \mathrm{H})$ & $\mathrm{H}-3, \mathrm{H}-7$ & $\begin{array}{l}\mathrm{H}-3, \mathrm{H}-4 \mathrm{~b}, \mathrm{H}-7, \\
\mathrm{H}-1^{\prime} \mathrm{a} / \mathrm{b}\end{array}$ \\
\hline 3 & 69.2 & $\begin{array}{l}5.10(q, J=2.6 \mathrm{~Hz}, \\
1 \mathrm{H})\end{array}$ & $\begin{array}{l}\mathrm{H}-2, \\
\mathrm{H}-4 \mathrm{a} / \mathrm{b}\end{array}$ & $\begin{array}{l}\mathrm{H}-2, \mathrm{H}-4 \mathrm{a} / \mathrm{b} \\
\mathrm{H}-5 \mathrm{a}, \mathrm{H}-7\end{array}$ & 69.4 & $\begin{array}{l}5.05(\mathrm{dt}, J=6.5, \\
3.2 \mathrm{~Hz}, 1 \mathrm{H})\end{array}$ & $\begin{array}{l}\mathrm{H}-2, \\
\mathrm{H}-4 \mathrm{a} / \mathrm{b}\end{array}$ & $\begin{array}{l}\mathrm{H}-2, \mathrm{H}-4 \mathrm{a} / \mathrm{b} \\
\mathrm{H}-5 \mathrm{a}, \mathrm{H}-7\end{array}$ \\
\hline $4 a$ & 28.0 & $\begin{array}{l}1.82(\mathrm{dddd}, J=14.7 \\
13.5,4.3,2.6 \mathrm{~Hz}, 1 \mathrm{H})\end{array}$ & $\begin{array}{l}\mathrm{H}-3, \mathrm{H}-4 \mathrm{~b} \\
\mathrm{H}-5 \mathrm{a} / \mathrm{b}\end{array}$ & $\begin{array}{l}\mathrm{H}-2, \mathrm{H}-3, \\
\mathrm{H}-4 \mathrm{~b}, \mathrm{H}-5 \mathrm{~b}, \\
\mathrm{H}-6\end{array}$ & 23.2 & $1.89(\mathrm{~m}, 1 \mathrm{H})$ & $\begin{array}{l}H-3, H-4 b \\
H-5 a / b\end{array}$ & $\begin{array}{l}\mathrm{H}-3, \mathrm{H}-4 \mathrm{~b} \\
\mathrm{H}-5 \mathrm{~b}, \mathrm{H}-7\end{array}$ \\
\hline $4 b$ & & $\begin{array}{l}2.06(\mathrm{dq}, J=14.0, \\
3.0 \mathrm{~Hz}, 1 \mathrm{H})\end{array}$ & $\begin{array}{l}\mathrm{H}-3, \mathrm{H}-4 \mathrm{a} \\
\mathrm{H}-5 \mathrm{a} / \mathrm{b}\end{array}$ & $\begin{array}{l}\mathrm{H}-3, \mathrm{H}-4 \mathrm{a} \\
\mathrm{H}-5 \mathrm{a} / \mathrm{b}\end{array}$ & & $1.96(\mathrm{~m}, 1 \mathrm{H})$ & $\begin{array}{l}\mathrm{H}-3, \mathrm{H}-4 \mathrm{a}, \\
\mathrm{H}-5 \mathrm{a} / \mathrm{b}\end{array}$ & $\begin{array}{l}\mathrm{H}-2, \mathrm{H}-3, \mathrm{H}-4 \mathrm{a}, \\
\mathrm{H}-5 \mathrm{a}, \mathrm{H}-1^{\prime} \mathrm{a} / \mathrm{b}\end{array}$ \\
\hline $5 a$ & 24.1 & $1.57(\mathrm{~m}, 1 \mathrm{H})$ & $\begin{array}{l}\mathrm{H}-4, \mathrm{H}-5 \mathrm{~b}, \\
\mathrm{H}-6\end{array}$ & $\begin{array}{l}\mathrm{H}-3, \mathrm{H}-4 \mathrm{a} / \mathrm{b} \\
\mathrm{H}-5 \mathrm{~b}, \mathrm{H}-6\end{array}$ & 22.8 & $1.66(\mathrm{~m}, 1 \mathrm{H})$ & $\begin{array}{l}H-4, H-5 b \\
H-6\end{array}$ & $\begin{array}{l}\mathrm{H}-2, \mathrm{H}-6, \mathrm{H}-4 \mathrm{~b}, \\
\mathrm{H}-5 \mathrm{~b}, \mathrm{H}-1^{\prime} \mathrm{b}, \\
\mathrm{H}-2^{\prime} \mathrm{a}\end{array}$ \\
\hline $5 b$ & & $\begin{array}{l}1.94(\mathrm{ddt}, J=10.2, \\
6.8,3.2 \mathrm{~Hz}, 1 \mathrm{H})\end{array}$ & $\begin{array}{l}\text { H-4, H-5a, } \\
\text { H-6 }\end{array}$ & $\begin{array}{l}\mathrm{H}-4 \mathrm{a} / \mathrm{b}, \mathrm{H}-5 \mathrm{a}, \\
\mathrm{H}-6, \mathrm{H}-1^{\prime} \mathrm{a} / \mathrm{b}, \\
\mathrm{H}-2^{\prime} \mathrm{a} / \mathrm{b}\end{array}$ & & $2.07(\mathrm{~m}, 1 \mathrm{H})$ & $\begin{array}{l}\mathrm{H}-4, \mathrm{H}-5 \mathrm{a}, \\
\mathrm{H}-6\end{array}$ & $\begin{array}{l}\text { H-4a, H-5a, } \\
\text { H-6 }\end{array}$ \\
\hline 6 & 58.5 & $3.18(\mathrm{~m}, 1 \mathrm{H})$ & $\begin{array}{l}\mathrm{H}-5 \mathrm{a} / \mathrm{b} \\
\mathrm{H}-1^{\prime}\end{array}$ & $\begin{array}{l}\mathrm{H}-4 a, H-5 b, \\
H-1 ' a / b, \\
H-2 ' a / b, \\
H-3^{\prime}-7 \text { ' }\end{array}$ & 53.5 & $3.43(\mathrm{~m}, 1 \mathrm{H})$ & $\begin{array}{l}\mathrm{H}-5 \mathrm{a} / \mathrm{b} \\
\mathrm{H}-1^{\prime}\end{array}$ & $\begin{array}{l}\text { H-5a/b, H-7, } \\
\text { H-1'a/b, H-2'a }\end{array}$ \\
\hline 7 & 15.5 & $\begin{array}{l}1.29(\mathrm{~d}, J=6.7 \mathrm{~Hz}, \\
3 \mathrm{H})\end{array}$ & $\mathrm{H}-2$ & $\begin{array}{l}\mathrm{H}-2, \mathrm{H}-3 \\
\mathrm{H}-2^{*}\end{array}$ & 13.5 & $1.31(\mathrm{~m}, 3 \mathrm{H})$ & $\mathrm{H}-2$ & $\begin{array}{l}\mathrm{H}-2, \mathrm{H}-3, \mathrm{H}-4 \mathrm{a}, \\
\mathrm{H}-5 \mathrm{~b}, \mathrm{H}-6\end{array}$ \\
\hline 1'a & 34.6 & $1.62(\mathrm{~m}, 1 \mathrm{H})$ & $\mathrm{H}-1^{\prime} \mathrm{b}, \mathrm{H}-2^{\prime}$ & $\begin{array}{l}H-1^{\prime} b, \\
H-2^{\prime} a / b, \\
H-3^{\prime}-7^{\prime}\end{array}$ & 30.6 & $1.67(\mathrm{~m}, 1 \mathrm{H})$ & $\begin{array}{l}\mathrm{H}-1^{\prime} b \\
\mathrm{H}-2^{\prime}\end{array}$ & $\begin{array}{l}H-2, H-6, \\
H-1^{\prime} b, H-2^{\prime} a / b\end{array}$ \\
\hline $1 ' b$ & & $1.72(\mathrm{~m}, 1 \mathrm{H})$ & $\mathrm{H}-1^{\prime} \mathrm{a}, \mathrm{H}-2^{\prime}$ & $\begin{array}{l}\text { H-1'a, } \\
\text { H-2'a/b, } \\
H-3^{\prime}-7 \text { ' }\end{array}$ & & $1.79(\mathrm{~m}, 1 \mathrm{H})$ & $\begin{array}{l}\text { H-1'a, } \\
\text { H-2' }\end{array}$ & $\begin{array}{l}H-2, H-6, \\
H-1^{\prime} a, H-2^{\prime} a / b\end{array}$ \\
\hline $2^{\prime} a$ & 26.2 & $1.40(\mathrm{~m}, 1 \mathrm{H})$ & $\begin{array}{l}H-1^{\prime}, \\
H-2^{\prime} b, H-3^{\prime}\end{array}$ & $\begin{array}{l}\mathrm{H}-1^{\prime} a / b, \\
\mathrm{H}-2^{\prime} b, \\
\mathrm{H}-3^{\prime}-7^{\prime}\end{array}$ & 26.9 & $1.40(\mathrm{~m}, 1 \mathrm{H})$ & $\begin{array}{l}\mathrm{H}-1^{\prime}, \\
\mathrm{H}-2^{\prime} \mathrm{b}, \\
\mathrm{H}-3^{\prime}\end{array}$ & $\begin{array}{l}H-1^{\prime} a / b, H-2^{\prime} b, \\
H-3^{\prime}-7^{\prime}\end{array}$ \\
\hline $2^{\prime} b$ & & $1.48(\mathrm{~m}, 1 \mathrm{H})$ & $\begin{array}{l}\text { H-1', } \\
\text { H-2'a, H-3' }\end{array}$ & $\begin{array}{l}\mathrm{H}-1^{\prime} \mathrm{a} / \mathrm{b}, \\
\mathrm{H}-2^{\prime} \mathrm{a}, \mathrm{H} 3^{\prime}-7^{\prime}\end{array}$ & & $1.42(\mathrm{~m}, 1 \mathrm{H})$ & $\begin{array}{l}\mathrm{H}-1^{\prime}, \\
\mathrm{H}-2^{\prime} \mathrm{a}, \\
\mathrm{H}-3^{\prime}\end{array}$ & $\begin{array}{l}\mathrm{H}-1^{\prime} \mathrm{a} / \mathrm{b}, \mathrm{H}-\mathrm{2}^{\prime} \mathrm{a}, \\
\mathrm{H}-3^{\prime}-7^{\prime}\end{array}$ \\
\hline $3^{\prime}-7^{\prime}$ & $30.4-30.5$ & $1.36(\mathrm{~m}, 10 \mathrm{H})$ & $\begin{array}{l}\mathrm{H}-2^{\prime} \mathrm{a} / \mathrm{b} \\
\mathrm{H}-8^{\prime}\end{array}$ & $\begin{array}{l}\mathrm{H}-8^{\prime}, \\
\mathrm{H}-9^{\prime} \mathrm{a} / \mathrm{b}, \mathrm{H}-6\end{array}$ & $30.4-30.6$ & $1.35(\mathrm{~m}, 10 \mathrm{H})$ & $\begin{array}{l}\mathrm{H}-2^{\prime} \mathrm{a} / \mathrm{b}, \\
\mathrm{H}-8^{\prime}\end{array}$ & $\begin{array}{l}\mathrm{H}-8^{\prime}, \mathrm{H}-9^{\prime} \mathrm{a} / \mathrm{b}, \\
\mathrm{H}-6\end{array}$ \\
\hline $8^{\prime}$ & 31.3 & $1.60(\mathrm{~m}, 2 \mathrm{H})$ & $\begin{array}{l}\text { H-7', } \\
\text { H-9'a/b }\end{array}$ & $\begin{array}{l}\text { H-3'-7', } \\
\text { H-9'a/b, H-3" }\end{array}$ & 31.3 & $\begin{array}{l}1.59(\mathrm{t}, J=7.3 \mathrm{~Hz}, \\
2 \mathrm{H})\end{array}$ & $\begin{array}{l}\text { H-7', } \\
\text { H-9'a/b }\end{array}$ & $\begin{array}{l}\text { H-3'-7', } \\
\text { H-9'a/b, H-3" }\end{array}$ \\
\hline 9'a & 31.0 & $\begin{array}{l}2.59(\mathrm{dt}, J=13.5 \\
7.7 \mathrm{~Hz}, 1 \mathrm{H})\end{array}$ & $\mathrm{H}-8^{\prime}, \mathrm{H}-9^{\prime} \mathrm{b}$ & $\begin{array}{l}H-8^{\prime}, H-9^{\prime} b, \\
H-3^{\prime \prime}\end{array}$ & 31.0 & $\begin{array}{l}2.59(\mathrm{dt}, J=13.4, \\
7.6 \mathrm{~Hz}, 1 \mathrm{H})\end{array}$ & $\begin{array}{l}\mathrm{H}-8^{\prime} \\
\mathrm{H}-\mathrm{g}^{\prime} \mathrm{b}\end{array}$ & $\begin{array}{l}H-8^{\prime}, H-9^{\prime} b \\
H-3^{\prime \prime}\end{array}$ \\
\hline $9^{\prime} b$ & & $\begin{array}{l}2.69(\mathrm{dt}, J=13.4, \\
7.6 \mathrm{~Hz}, 1 \mathrm{H})\end{array}$ & $\mathrm{H}-8^{\prime}, \mathrm{H}-9$ 'a & $\begin{array}{l}\text { H-8', H-9'a, } \\
\text { H-3" }\end{array}$ & & $\begin{array}{l}2.69(\mathrm{dt}, J=13.4, \\
7.6 \mathrm{~Hz}, 1 \mathrm{H})\end{array}$ & $\begin{array}{l}\text { H-8', } \\
\text { H-9'a }\end{array}$ & $\begin{array}{l}\text { H-8', H-9'a, } \\
\text { H-3" }\end{array}$ \\
\hline $1^{\prime \prime}$ & 150.3 & - & - & - & 150.3 & - & - & - \\
\hline $2^{\prime \prime}$ & 135.2 & - & - & - & 135.1 & - & - & - \\
\hline $3^{\prime \prime}$ & 117.3 & $\begin{array}{l}6.57(\mathrm{~d}, J=3.0 \mathrm{~Hz}, \\
1 \mathrm{H})\end{array}$ & $\mathrm{H}-5^{\prime \prime}$ & $\begin{array}{l}\text { H-3'-7', } \\
\text { H-8', H-9'a/b }\end{array}$ & 117.3 & $\begin{array}{l}6.57(\mathrm{~d}, J=3.0 \mathrm{~Hz}, \\
1 \mathrm{H})\end{array}$ & $\mathrm{H}-5^{\prime \prime}$ & $\begin{array}{l}\mathrm{H}-3-\mathrm{H}^{\prime}, \mathrm{H}-8^{\prime}, \\
\mathrm{H}-9^{\prime} \mathrm{a} / \mathrm{b}\end{array}$ \\
\hline $4^{\prime \prime}$ & 153.5 & - & - & - & 153.5 & - & - & - \\
\hline $5^{\prime \prime}$ & 113.8 & $\begin{array}{l}6.55(\mathrm{dd}, J=8.7 \\
3.0 \mathrm{~Hz}, 1 \mathrm{H})\end{array}$ & $\mathrm{H}-6^{\prime \prime}$ & H-6" & 113.8 & $\begin{array}{l}6.55(\mathrm{dd}, J=8.7 \\
3.0 \mathrm{~Hz}, 1 \mathrm{H})\end{array}$ & $\mathrm{H}-6^{\prime \prime}$ & $\mathrm{H}-6^{\prime \prime}$ \\
\hline $6^{\prime \prime}$ & 118.5 & $\begin{array}{l}7.01(\mathrm{~d}, J=8.7 \mathrm{~Hz}, \\
1 \mathrm{H})\end{array}$ & $\mathrm{H}-5^{\prime \prime}$ & $\mathrm{H}-5^{\prime \prime}, \mathrm{H}-1^{\prime \prime \prime}$ & 118.5 & $\begin{array}{l}7.01(\mathrm{~d}, J=8.7 \mathrm{~Hz} \\
1 \mathrm{H})\end{array}$ & $\mathrm{H}-5^{\prime \prime}$ & $\mathrm{H}-5^{\prime \prime}, \mathrm{H}-\mathbf{1}^{\prime \prime \prime}$ \\
\hline $1^{\prime \prime \prime}$ & 104.0 & $\begin{array}{l}4.74(\mathrm{~d}, J=7.7 \mathrm{~Hz}, \\
1 \mathrm{H})\end{array}$ & $\mathrm{H}-2^{\prime \prime \prime}$ & $\begin{array}{l}\text { H-6", } \\
\text { H-2"'-5"' }\end{array}$ & 104.0 & $\begin{array}{l}4.73(\mathrm{~d}, J=7.6 \mathrm{~Hz} \\
1 \mathrm{H})\end{array}$ & $\mathrm{H}-2^{\prime \prime \prime}$ & H-6", H-2"'-5"' \\
\hline $2^{\prime \prime \prime}$ & 75.2 & $3.44(\mathrm{~m}, 1 \mathrm{H})$ & $\mathrm{H}-1^{\prime \prime \prime}$ & $\mathrm{H}-1^{\prime \prime \prime}$ & 75.2 & $3.45(\mathrm{~m}, 1 \mathrm{H})$ & $\mathrm{H}-1^{\prime \prime \prime}$ & $\mathrm{H}-1^{\prime \prime \prime}$ \\
\hline
\end{tabular}


- Table 3 Continued

\begin{tabular}{|c|c|c|c|c|c|c|c|c|}
\hline \multirow[b]{2}{*}{$\begin{array}{l}\text { Posi- } \\
\text { tion }\end{array}$} & \multicolumn{4}{|l|}{$3 a$} & \multicolumn{4}{|l|}{$3 b$} \\
\hline & $\delta_{\mathrm{C}}[\mathrm{ppm}]$ & $\begin{array}{l}\delta_{\mathrm{H}}[\mathrm{ppm}] \text { (mult., } \\
J / \mathrm{Hz}, \mathrm{No} . \mathrm{H})\end{array}$ & $\cos Y$ & NOESY & $\delta_{\mathrm{C}}[\mathrm{ppm}]$ & $\begin{array}{l}\delta_{\mathrm{H}}[\mathrm{ppm}] \text { (mult., } \\
J / \mathrm{Hz}, \text { No. H) }\end{array}$ & $\cos Y$ & NOESY \\
\hline $3^{\prime \prime \prime}$ & 78.4 & $3.44(\mathrm{~m}, 1 \mathrm{H})$ & $\mathrm{H}-4^{\prime \prime \prime}$ & $\mathrm{H}-1^{\prime \prime \prime}$ & 78.4 & $3.45(\mathrm{~m}, 1 \mathrm{H})$ & $\mathrm{H}-4^{\prime \prime \prime}$ & $\mathrm{H}-1^{\prime \prime \prime}$ \\
\hline $4^{\prime \prime \prime}$ & 71.5 & $3.38(\mathrm{~m}, 1 \mathrm{H})$ & $\mathrm{H}-3^{\prime \prime \prime}$ & H-1"', H-6"'a/b & 71.6 & $3.38(\mathrm{~m}, 1 \mathrm{H})$ & $\mathrm{H}-3^{\prime \prime \prime}$ & H-1"', H-6"'a/b \\
\hline $5^{\prime \prime \prime}$ & 78.0 & $3.38(\mathrm{~m}, 1 \mathrm{H})$ & $H-6^{\prime \prime \prime}$ & H-1"', H-6"'a/b & 78.0 & $3.38(\mathrm{~m}, 1 \mathrm{H})$ & $\mathrm{H}-6^{\prime \prime \prime}$ & H-1"', H-6"'a/b \\
\hline 6"'a & 62.6 & $\begin{array}{l}3.71(\mathrm{dd}, J=11.9 \\
5.2 \mathrm{~Hz}, 1 \mathrm{H})\end{array}$ & $\begin{array}{l}\text { H-5"', } \\
\text { H-6"'b }\end{array}$ & $H-6^{\prime \prime \prime} b$ & 62.7 & $3.72(\mathrm{~m}, 1 \mathrm{H})$ & $\begin{array}{l}\mathrm{H}-5^{\prime \prime \prime}, \\
\mathrm{H}-6^{\prime \prime \prime} \mathrm{b}\end{array}$ & $H-6^{\prime \prime \prime} b$ \\
\hline $6^{\prime \prime \prime} \mathrm{b}$ & & $\begin{array}{l}3.89(\mathrm{dd}, J=12.0 \\
2.2 \mathrm{~Hz}, 1 \mathrm{H})\end{array}$ & $\begin{array}{l}\text { H-5"', } \\
\text { H-6"'a }\end{array}$ & H-6"'a & & $\begin{array}{l}3.89(\mathrm{dd}, J=12.1 \\
2.1 \mathrm{~Hz}, 1 \mathrm{H})\end{array}$ & $\begin{array}{l}\text { H-5"', } \\
\text { H-6"'a }\end{array}$ & H-6"'a \\
\hline $1^{*}$ & 171.3 & - & - & - & 171.3 & - & - & - \\
\hline $2^{*}$ & 20.7 & $2.15(\mathrm{~s}, 3 \mathrm{H})$ & - & $\mathrm{H}-3, \mathrm{H}-7$ & 20.7 & $2.13(\mathrm{~s}, 3 \mathrm{H})$ & - & - \\
\hline
\end{tabular}

- Table 4 Extract yields after lyophilization from different Tilia species and plant organs in relation to the used solvent system and respective amounts of each Tilia alkaloid [\%], related to the dry extract. DER: drug-extract-ratio; 1a: tiliine A, 1b: tiliine B, 2a: tiliamine A, 2b: tiliamine B, 3a: tilacetine A, 3b: tilacetine B.

\begin{tabular}{|c|c|c|c|c|c|c|c|c|c|c|c|c|}
\hline & \multirow[t]{2}{*}{ Plant material } & \multirow{2}{*}{$\begin{array}{l}\text { Extraction } \\
\text { solvent }\end{array}$} & \multirow{2}{*}{$\begin{array}{l}\text { Dried plant } \\
\text { material [g] }\end{array}$} & \multirow{2}{*}{$\begin{array}{l}\text { Yield } \\
\text { [g] }\end{array}$} & \multirow{2}{*}{$\begin{array}{l}\text { Yield } \\
{[\%, w / w]}\end{array}$} & \multirow[t]{2}{*}{ DER } & \multicolumn{6}{|c|}{ Amount of Tilia alkaloids [mg/g dry extract] } \\
\hline & & & & & & & 1a & $1 b$ & $2 a$ & $2 b$ & $3 a$ & $3 b$ \\
\hline 1 & Tiliae flos & $\begin{array}{l}\text { acetone/water } \\
(7: 3 \mathrm{v} / \mathrm{v})\end{array}$ & 1300.0 & 225.95 & 17.4 & $5.7: 1$ & 1.71 & 1.05 & $<0.1$ & $<0.1$ & 0.89 & 1.27 \\
\hline II & $\begin{array}{l}\text { Tilia platyphyllos } \\
\text { flowers }\end{array}$ & $\begin{array}{l}\text { acetone/water } \\
(7: 3 \mathrm{v} / \mathrm{v})\end{array}$ & 151.0 & 30.84 & 20.4 & $4.9: 1$ & 0.90 & 0.43 & $<0.1$ & $<0.1$ & 1.18 & 0.79 \\
\hline III & $\begin{array}{l}\text { Tilia cordata } \\
\text { flowers }\end{array}$ & $\begin{array}{l}\text { acetone/water } \\
(7: 3 \mathrm{v} / \mathrm{v})\end{array}$ & 68.0 & 12.01 & 17.6 & $5.7: 1$ & 0.61 & 0.24 & $<0.1$ & $<0.1$ & 0.26 & 0.85 \\
\hline IV & $\begin{array}{l}\text { Tilia platyphyllos } \\
\text { flowers without } \\
\text { bracts }\end{array}$ & $\begin{array}{l}\text { acetone/water } \\
(7: 3 \mathrm{v} / \mathrm{v})\end{array}$ & 10.0 & 1.91 & 19.1 & $5.2: 1$ & 0.72 & 0.32 & $<0.1$ & $<0.1$ & 0.35 & 1.08 \\
\hline v & $\begin{array}{l}\text { Tilia platyphyllos } \\
\text { bracts }\end{array}$ & $\begin{array}{l}\text { acetone/water } \\
(7: 3 \mathrm{v} / \mathrm{v})\end{array}$ & 10.0 & 0.71 & 7.1 & $14.1: 1$ & 0.55 & 0.24 & $<0.1$ & $<0.1$ & 0.36 & 1.43 \\
\hline $\mathrm{VI}$ & $\begin{array}{l}\text { Tilia platyphyllos } \\
\text { leaves }\end{array}$ & $\begin{array}{l}\text { acetone/water } \\
(7: 3 \mathrm{v} / \mathrm{v})\end{array}$ & 10.0 & 1.09 & 10.9 & $9.2: 1$ & 0.17 & 0.10 & $<0.1$ & $<0.1$ & 0.38 & 0.90 \\
\hline VII & Tiliae flos & ethanol 96\% & 10.0 & 0.23 & 2.3 & $43.5: 1$ & 1.07 & 0.50 & $<0.1$ & $<0.1$ & 0.39 & 0.88 \\
\hline VIII & Tiliae flos & ethanol $50 \%$ & 10.0 & 1.67 & 16.7 & $6.0: 1$ & 0.80 & 0.38 & $<0.1$ & $<0.1$ & 0.22 & 0.50 \\
\hline IX & Tiliae flos & infuse & 1.5 & 0.21 & 13.9 & $7.2: 1$ & 0.46 & 0.20 & $<0.1$ & $<0.1$ & 0.27 & 0.38 \\
\hline
\end{tabular}

NMR studies due to the very low amounts obtained during the isolation process.

To determine the absolute amount of the 6 Tilia alkaloids in different plant materials, extracts were prepared from T. platyphyllos and $T$. cordata, as well as from Tiliae flos, which represents a mixture of both species, including also potential hybrids according to the European Pharmacopoeia. Additionally, extracts from different organs of $T$. platyphyllos (flowers without bracts, leaves) were prepared, and various extraction solvents were tested for their potential to solubilize the alkaloids (acetone/water 7:3, ethanol $96 \%$, and ethanol 50\%). Since lime flowers are traditionally used for medicinal purposes as herbal teas prepared by hot water extraction, an infusion was also included in the investigation. Quantification was performed using HPLC-ESI-qTOF after calibration with the respective alkaloids in concentrations of $5.0-0.1 \mu \mathrm{g} / \mathrm{mL}$ each. The amounts of the individual alkaloids are displayed in

\section{- Table 4 and Fig. 6.}

Tilia alkaloids were detected in all investigated extracts. Best extraction was achieved by use of acetone/water mixture as solvent while lower amounts were extracted by ethanol and ethanol/water mixtures. Also the hot water extract contained relevant alkaloid amounts, but less than had been extracted by organic solvents. It is important to note that tiliamine $A$ and tiliamine $B$ could be detected in all extracts, but the amount was lower than the lowest calibration level. Therefore, the amount of tiliamine $A$ and tiliamine $B$ has to be declared as $<0.1 \mathrm{mg} / \mathrm{g}$ extract. This is in contrast to results of the isolation, where tiliamine $A$ and tiliamine $B$ were obtained in the highest yields. This might be explained by a 


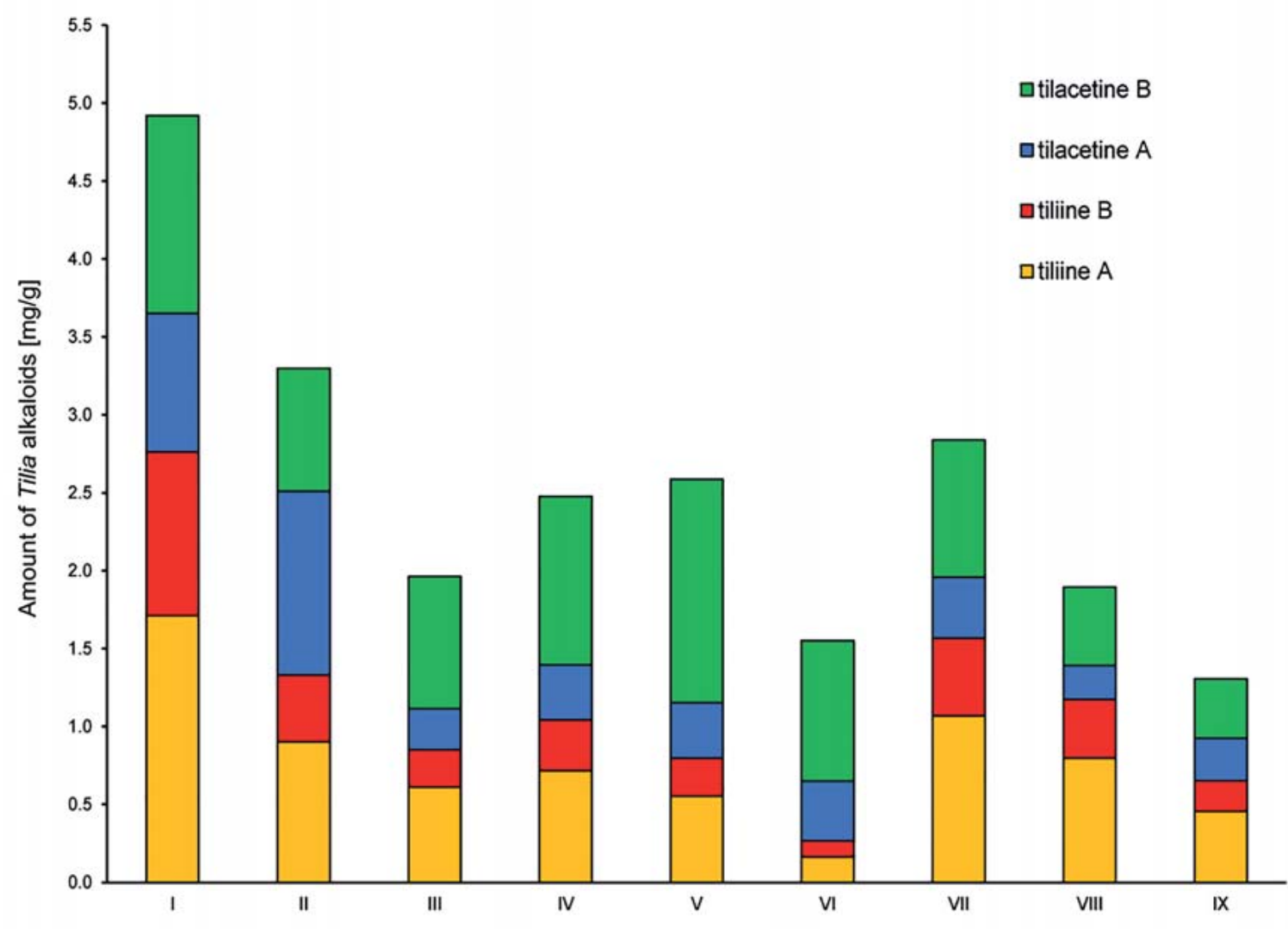

D Fig. 6 Absolute amounts $[\mathrm{mg} / \mathrm{g}]$ of Tilia alkaloids in extracts, obtained by different solvents or from different plant material. I: Tiliae flos (acetone/water 7:3), II: Tilia platyphyllos flowers (acetone/water 7:3), III: Tilia cordata flowers (acetone/water 7:3), IV: Tilia platyphyllos flowers without bracts (acetone/water 7:3), V: Tilia platyphyllos bracts (acetone/water 7:3), VI: Tilia platyphyllos leaves (acetone/water 7:3), VII: Tiliae flos (ethanol $96 \%$ ), VIII: Tiliae flos (ethanol 50\%), IX: Tiliae flos (infusion). The amounts of tiliamine A and tiliamine B are $<0.1 \mathrm{mg} / \mathrm{g}$ for all samples and are therefore not displayed in this figure.

specific enrichment regarding these compounds or by deacetylation of acetylated derivatives.

During the alkaloid quantification, the alkaloids were found to be present in T. cordata as well as in T. platyphyllos. Interestingly, the alkaloids can be extracted from leaves, flowers, and bracts of T. platyphyllos, indicating that they are widely distributed all over the plant and are not exclusively accumulated in the flowers.

\section{Discussion}

Three pairs of previously undescribed alkaloids have been identified from lime flower. They include the 3,4-dihydro- $2 \mathrm{H}$-pyrrole alkaloids tiliines $A$ and $B$, the piperidine alkaloids tiliamines $A$ and $B$, and the acetylated piperidine alkaloids tilacetines $A$ and $B$. We assume that the nonacetylated products are in part due to de-esterification during the isolation process, which uses ammonia for alkalization. On the other side, we can identify by HPLC the nonacetylated compounds also in extracts, which had not been in contact with alkaline solvents. This indicates that both nonesterified and acetylated compounds are formed biosynthetically. The proposed structure of the glycosylated alkyl-piperidine and alkyl-dihydropyrrole alkaloids is in good accordance to some already known alkaloids with similar structural features. Melhaoui et al. reported the existence of an alkaloid called irniine from Arisarum vulgare (Araceae), with an N-methyl-pyrrolidine heterocycle linked to a phenyl group via a C9 alkyl chain [17]. Additionally, the authors isolated a 2-methyl-piperidin-3-ol alkaloid called irnigaine with the same phenylalkyl chain [17]. Su et al. identified a 2-methylpyrrolidin-3-ol alkaloid with a C10 alkyl chain and a phenyl ring in Arisaema franchetianum (Araceae) tubers [18]. In rhizomes from Alocasia macrorrhiza (Araceae), Huang et al. detected a variety of 2-methyl-piperidin-3-ol alkaloids again linked to a phenyl ring via a C9 alkyl chain [19]. As all these plants from the Araceae family belong to the monocotyledons, it is interesting that compounds with similar structural features, as the Tilia alkaloids described here, appear also in dicotyledons. Piperidine alkaloids with 2methyl-3-hydroxy-6-alkyl (saturated) substitution but without phenyl substituent at the end of the alkyl chain have been described in the genera Senna, Cassia, and Prosopis (Fabaceae) [2025]. Similar piperidine alkaloids with predominantly unsaturated alkyl chains have been found in the marine hydroid Corydendrium parasiticum (Clavidae) and in the genus Microcos (Malvaceae) [12, 26-30]. This genus was formerly classified into the family Tiliaceae, which is now turned into the subfamily, Tilioideae, within 
the Malvaceae family. At present, the genus Microcos is classified in the subfamily, Grewioideae. Apart from the genus Microcos, alkaloids in general appear in the family of Malvaceae up to now only in the genus Sida (indoquinoline alkaloids) [12-14].

Despite detailed structural investigation on the isolated alkaloids, the absolute configuration at the heterocycle still remains to be determined. Unfortunately, CD spectroscopic investigations of the alkaloids did not turn out to be helpful, as the chromophore of the phenyl system is too far away from the relevant piperidine/ dihydropyrrole system. Also, derivatization with Mosher's acid chloride and subsequent NMR investigations failed, as the used reagents reacted not only with the hydroxyl function of the heterocycle, but also with the carbohydrate part of the molecule, leading to highly complex mixtures that hamper unambiguous NMR interpretation. Using NMR data sets for already known compounds with similar structural features, it might be interesting to refer to leptophyllin $B$, which has a $2 R, 3 R$, 6R configurated 2methyl-6-alkyl piperidin-3-ol heterocycle [21]. NMR data of this compound are very similar to those of the above described compound $2 \mathrm{a}$, so that it may be speculated that the piperidine heterocycle of compound 2 a could have a $2 R, 3 R$, 6R configuration as well. Our investigation reveals that lime flowers contain interesting alkaloids not described in nature until now. Taking the quantification data into account, an effective isolation also could be performed in the future from leaf material, which is easily and economically available.

Further studies are warranted to investigate the role of these alkaloids as a potential plant defense system and to explore their biological properties in order to determine if pharmacological activities related to symptoms of the common cold and/or mental stress could be affected by these compounds or even by the extract.

\section{Materials and Methods}

\section{Plant material}

Dried and cut herbal material from lime flower (batch no. 18005 504, voucher sample IPBP 519) was obtained in a quality according to the specifications of the European Pharmacopoeia (Ph. Eur. 9.0) [3] from Caesar \& Loretz. Plant material from T. platyphyllos and T. cordata was collected on June 16, 2019 and July 2, 2019 at the Medicinal Plant Botanical Garden of the University of Münster (Germany, 51 ${ }^{\circ} 57^{\prime} 54.5^{\prime \prime} \mathrm{N} 7^{\circ} 36^{\prime} 24.4^{\prime \prime} \mathrm{E}$ ) and identified by the authors $\mathrm{AH}$ and NS. Reference samples (voucher samples IPBP 512 and IPBP 513) are deposited in the Institute of Pharmaceutical Biology and Phytochemistry (Münster, Germany). Plant material of T. platyphyllos was again collected on June 22, 2020 and manually separated into flowers, floral bracts, and leaves (voucher samples IPBP 525, IPBP 526, and IPBP 527).

\section{General experimental procedures}

If not stated otherwise, solvents and reagents were of analytical quality and obtained from VWR International. Consumables were obtained from Sarstedt. Ultrapure water was produced by a Millipore simplicity 185 system. UV/VIS spectroscopic data were recorded on a Hitachi U-2900 spectrophotometer at room temper- ature using a Hellma $10 \mathrm{~mm}$ quartz glass cuvette. The samples were dissolved in methanol at a concentration of $0.1 \mathrm{mg} / \mathrm{mL}$, and methanol was used a blank. The UV/Vis spectra are shown in the Supporting Information (Fig. 3S, Supporting Information). Oneand 2-dimensional NMR spectroscopic experiments were carried out using an Agilent DD2 spectrometer (Agilent Technologies, Santa Clara, USA) at $600 \mathrm{MHz}\left({ }^{1} \mathrm{H}\right)$ or $150 \mathrm{MHz}\left({ }^{13} \mathrm{C}\right)$ at $299 \mathrm{~K}$. Samples were dissolved in methanol- $d_{4}(\geq 99.8 \% D)$. Chemical shifts (ppm) were referenced to the residual signals of nondeuterated solvent ( ${ }^{1} \mathrm{H}$ : $4.870 \mathrm{ppm}$ and $\left.3.31 \mathrm{ppm}\right)$ and the ${ }^{13} \mathrm{C}$ isotope signal at $49.00 \mathrm{ppm}$. The 1D and 2D NMR spectra are shown in the Supporting Information (Fig. 6S to 11S, Supporting Information).

\section{Extraction of lime flowers and isolation of alkaloids}

Extraction was carried out as displayed in $\mathbf{F i g} \mathbf{1}$ according to a method described recently [9]. Dried and cut lime flower $(1.3 \mathrm{~kg})$ was extracted in aliquots of $100 \mathrm{~g}(2 \times 1000 \mathrm{~mL}$ with a mixture of cold acetone/water $(7: 3 \mathrm{v} / \mathrm{v})$ under exclusion of direct light. After removal of acetone under vacuo, chlorophyll was removed from the extracts by liquid-liquid partitioning of the remaining aqueous phase with petroleum ether $(5 \times 600 \mathrm{~mL}$ for each extraction step), resulting in $225 \mathrm{~g}(17 \% \mathrm{w} / \mathrm{w}$, related to the starting material) of extract $A$.

A portion $(80 \mathrm{~g})$ of extract A was fractionated by Bond Elute Plexa PCX cationic exchange solid phase extraction (SPE) (200 mg, $6 \mathrm{~mL}$, Agilent). The extract was dissolved in $\mathrm{H}_{3} \mathrm{PO}_{4}(2 \%$ in methanol/water, $[1: 1 \mathrm{v} / \mathrm{v}])$ at a concentration of $100 \mathrm{mg} / \mathrm{mL}$. The SPE separation was performed in accordance with the specifications given by the manufacturer. After activation with methanol and equilibration with water, $3 \mathrm{~mL}$ of the sample solution was loaded on the cartridge and subsequently eluted, each with $6 \mathrm{~mL}$ of formic acid ( $2 \%$ in water), methanol/acetonitrile ( $1: 1 \mathrm{v} / \mathrm{v}), 5 \%$ $\mathrm{NH}_{3}$ in methanol/acetonitrile $(1: 1 \mathrm{v} / \mathrm{v})$, and $5 \% \mathrm{NH}_{3}$ in methanol/ water $(1: 1 \mathrm{v} / \mathrm{v})$. Every elution step yielded a fraction that was subsequently monitored by UHPLC-ESI-MS on RP18 stationary phase, as described below. Tilia alkaloids eluted as basic fraction B with $5 \% \mathrm{NH}_{3}$ in methanol/acetonitrile, yielding $1.42 \mathrm{~g}(1.78 \%[\mathrm{w} / \mathrm{w}] \mathrm{re}-$ lated to the extract $\mathrm{A}$ and $0.31 \%$, related to the dried plant material).

Further fractionation of fraction B was performed on Sephadex LH-20 $(345 \times 30 \mathrm{~mm}$; bed volume $244 \mathrm{~mL}) ; 1.42 \mathrm{~g}$ of B was dissolved in $15 \mathrm{~mL}$ of $5 \% \mathrm{NH}_{3}$ in ethanol/water $(1: 1 \mathrm{v} / \mathrm{v})$, and successively separated in 3 portions of $5 \mathrm{~mL}$ each. Isocratic elution was performed with $250 \mathrm{~mL}$ of $5 \% \mathrm{NH}_{3}$ in ethanol/water $(1: 1 \mathrm{v} / \mathrm{v})$ at a flow rate of $0.8 \mathrm{~mL} / \mathrm{min}$. This fractionation yielded 25 fractions of $10 \mathrm{~mL}$. Monitoring of all fractions by UHPLC-ESI-MS indicated that the alkaloids, together with minor amounts of nonalkaloid compounds, eluted between 180 and $210 \mathrm{~mL}$. Alkaloid-containing fractions were combined, yielding $367 \mathrm{mg}$ of a Tilia alkaloids-enriched fraction $C(0.46 \%[w / w]$ related to the extract $A)$. Fraction $C$ accounted for $0.08 \%$ related to the dried plant material.

Final isolation and purification of individual alkaloids from fraction $C$ were performed by preparative HPLC. The system consisted of a Waters Quaternary Gradient Module 2545, a Photodiode Array Detector 2998, an Autosampler 2707, a Waters Prep Degasser, and a Waters Fraction Collector III. Data were recorded and analyzed with Waters ChromScope v1.40 Beta software. A Nucleodur 
C18 HTec column $(5 \mu \mathrm{m}, 250 \times 21 \mathrm{~mm}$, Macherey-Nagel) was used for separation. The mobile phase consisted of water/trifluoroacetic acid (98:2 v/v) (A) and acetonitrile/trifluoroacetic acid $(98: 2 \mathrm{v} / \mathrm{v})(\mathrm{B})$. The following gradient was applied: 0 to $16 \mathrm{~min}$ : linear from 0 to $18 \% \mathrm{~B}$; 16 to $56 \mathrm{~min}$ : linear from 18 to $30 \% \mathrm{~B}$; 56 to 64 min: linear from 30 to $100 \%$ B; 64 to $68 \mathrm{~min}$ : isocratic at $100 \% \mathrm{~B}$; 68 to $72 \mathrm{~min}$ : linear from 100 to $0 \% \mathrm{~B} ; 72$ to $80 \mathrm{~min}$ : isocratic at $0 \% \mathrm{~B}$. The flow rate was $10.0 \mathrm{~mL} / \mathrm{min}$. Column temperature: ambient temperature in an air-conditioned lab with $20^{\circ} \mathrm{C}$. Sample concentration: $20 \mathrm{mg} / \mathrm{mL}$. Injection volume: $1 \mathrm{~mL}$. Number of injections: 19 . This procedure yielded compounds 1a (3.9 mg, $\left.t_{R}=38 \mathrm{~min}\right), \quad 1 b \quad\left(3.9 \mathrm{mg}, t_{R}=39 \mathrm{~min}\right), 2 \mathrm{a} \quad(5.3 \mathrm{mg}$, $\left.t_{R}=44 \mathrm{~min}\right), 2 b\left(6.9 \mathrm{mg}, t_{R}=45 \mathrm{~min}\right)$, 3a $\left(2.6 \mathrm{mg}, t_{R}=53 \mathrm{~min}\right)$, and $3 \mathrm{~b}\left(2.0 \mathrm{mg}, t_{\mathrm{R}}=55 \mathrm{~min}\right)$.

\section{Monitoring of fractions by UHPLC}

SPE, Sephadex LH-20, and preparative HPLC-fractions were monitored for the presence of Tilia alkaloids using an UHPLC-ESI-MS system and an Acquity UPLC HSS T3 $(1.8 \mu \mathrm{m}, 2.1 \times 100 \mathrm{~mm})$ column (Waters). Mobile phase: (A) water with formic acid $0.1 \%$; (B) acetonitrile with $0.1 \%$ formic acid; 0 to 4 min: linear from 0 to $18 \%$ B; 4 to 14 min: 18 to $30 \% \mathrm{~B}$; 14 to $16 \mathrm{~min}$ : 30 to $100 \% \mathrm{~B}$; 16 to 17 min: isocratic at $100 \% \mathrm{~B} ; 17$ to $18 \mathrm{~min}$ : 100 to $0 \% \mathrm{~B} ; 18$ to 20 min: isocratic at $0 \% \mathrm{~B}$. Column temperature: $40{ }^{\circ} \mathrm{C}$. Flow rate: $0.5 \mathrm{~mL} / \mathrm{min}$. Injection volume: $4 \mu \mathrm{L}$. Eluted compounds were detected using a Waters PDA e $\lambda$ over a wavelength range of $\lambda=200$ to $800 \mathrm{~nm}$ and a Waters QDa mass spectrometer in the positive ion mode with a cone voltage of $15 \mathrm{~V}$ and a capillary voltage of $0.8 \mathrm{~V}$.

\section{UHPLC-HR-MS analysis}

UHPLC-ESI-qTOF-MS analysis was performed using a Dionex Ultimate 3000 RS Liquid Chromatography System on a Waters Acquity UPLC BEH C18 $(2.1 \times 100 \mathrm{~mm}, 1.7 \mu \mathrm{m})$ column at a temperature of $40{ }^{\circ} \mathrm{C}$. Injection volume: $10 \mu \mathrm{L}$. Flow rate: $0.4 \mathrm{~mL} / \mathrm{min}$. Samples were dissolved in methanol/water $(1: 9 \mathrm{v} / \mathrm{v})$ at a concentration of $10 \mathrm{mg} / \mathrm{mL}$. The mobile phase consisted of water with $0.1 \%$ formic acid (A) and acetonitrile with $0.1 \%$ formic acid (B). Gradient: $t_{R} 0.00$ to 9.00 min linear from $15 \% B$ initially to $38 \% B$; 9.00 to 9.02 min linear from 38 to $100 \%$ B; 9.02 to 15.00 min isocratic at $100 \% \mathrm{~B} ; 15.00$ to 15.10 min linear from 100 to $15 \% \mathrm{~B}$; 15.10 to 20.00 min isocratic equilibration at $15 \%$ B. Eluted compounds were detected using a Dionex Ultimate DAD-3000 RS over a wavelength range of $\lambda=200$ to $400 \mathrm{~nm}$ and a Bruker Daltonics micrOTOF-QII time-of-flight mass spectrometer equipped with an Apollo electrospray ionization source in positive mode at $3 \mathrm{~Hz}$ over a mass range of $\mathrm{m} / \mathrm{z} 50-1500$ using the following instrument settings: nebulizer gas nitrogen: 3.0 bar; dry gas nitrogen: $9 \mathrm{~L}$ min, $200{ }^{\circ} \mathrm{C}$; capillary voltage: $4500 \mathrm{~V}$; end plate offset: $500 \mathrm{~V}$; transfer time: $100 \mu \mathrm{s}$, prepulse storage: $6 \mu \mathrm{s}$, collision energy: $8 \mathrm{eV}$. MS/MS scans were triggered by AutoMS2 settings within a range of $\mathrm{m} / \mathrm{z} 50-1500$, using a collision energy of $70 \mathrm{eV}$ and collision cell RF of $130 \mathrm{Vpp}$. The extracted ion chromatograms of extract $A$ from lime flowers and the respective $M^{2}$ spectra are shown in the Supporting Information (Fig. 1S and 2S, Supporting Information).

\section{Hydrolysis of alkaloid glycosides and identification of hexose residue}

Alkaloid glycosides in Sephadex LH-20 fraction C (3 mg) were hydrolyzed by addition of $23 \%$ trifluoroacetic acid (TFA) at $120^{\circ} \mathrm{C}$ for $1 \mathrm{~h}$ as described by Albersheim et al. [31]. After removal of TFA by 3 washing steps each with $2 \mathrm{~mL}$ methanol/water $(1: 1 \mathrm{v} / \mathrm{v})$, the released carbohydrates were identified by TLC on silica gel G60 F254 $10 \times 20 \mathrm{~cm}$ plates and compared to the respective reference carbohydrates. Mobile phase: $n$-propanol/water/ethanol (7:2:1 $v / v / v)$. Spray reagent: ethanolic thymol/sulfuric acid solution. The chromatogram is shown in the Supporting Information (Fig. 4S).

Capillary zone electrophoresis (CZE) was performed after derivatization of the monosaccharides as described by Noe et al. [15] on a Beckman Coulter P/ACE MDQ. Separation parameters: fused silica capillary $70 / 77 \mathrm{~cm} \times 50 \mu \mathrm{m}$ i.d. running buffer: $\mathrm{Na}_{2} \mathrm{~B}_{2} \mathrm{O}_{7}$ $50 \mathrm{mM} \mathrm{pH} 10.3$, acetonitrile $4.4 \mathrm{~mol} / \mathrm{L}$ added. Injection: 5 to $10 \mathrm{~s}$ at 0.5 psi. Voltage: $30 \mathrm{kV}$. Detection: $\lambda=200 \mathrm{~nm}$. Software: 32 Karat version 5.0 (Beckman Coulter). The electropherograms are shown in the Supporting Information (Fig. 5S).

\section{Quantification of Tilia alkaloids}

For quantification of the alkaloids, 9 different extracts from different plant samples were investigated. In addition to extract $A$ from commercially available lime flower, self-collected plant material from either $T$. cordata or $T$. platyphyllos was extracted with acetone/water $(7: 3 \mathrm{v} / \mathrm{v})$ as mentioned above. Plant material obtained from $T$. platyphyllos was divided into flowers, floral bracts, and leaves, and all plant parts were separately extracted and investigated. Additionally, the commercially available lime flower batch was extracted with ethanol $96 \%$ and ethanol $50 \%$. A lime flower infusion was prepared by adding $150 \mathrm{~mL}$ of boiling water to $1.5 \mathrm{~g}$ of commercially available lime flower. After $15 \mathrm{~min}$, the plant material was removed by filtration, and the hot water extract was lyophilized. Quantification was performed using the above mentioned UHPLC-ESI-qTOF system, with the following modifications: sample concentration: $1 \mathrm{mg} / \mathrm{mL}$, dissolved in methanol/water $(1: 9 v / v)$, injection volume $5 \mu \mathrm{L}$, number of injections: 2 (calibrants), 3 (samples), deactivated Auto-MS2 function. Calibration solutions of the 6 Tilia alkaloids were prepared in methanol/water $(1: 9 \mathrm{v} / \mathrm{v})$ at following 6 concentrations: $5.0,2.0,1.0,0.5,0.2$, and $0.1 \mu \mathrm{g} / \mathrm{mL}$. Quantification was based on the analysis of extracted ion chromatograms of the respective $\mathrm{m} / \mathrm{z}$ values 510,512 , and 554 by QuantAnalysis software (Bruker) and Microsoft Excel. Although peaks of the diastereomers (e.g., m/z 510) were not baseline separated, the displayed chromatographic system achieved the best separation of tested systems. Respective peaks were divided at the peak valley for integration. The respective yields obtained from the extracts and the concentration of the 6 Tilia alkaloids in the respective extracts are shown in $>$ Table 4 and Fig. 6.

\section{Compound characterization}

Compound 1a (tiliine A)

Pale yellow oil. HR-ESI-MS: m/z $510.3081[\mathrm{M}+\mathrm{H}]^{+}$(calculated for $\left[\mathrm{C}_{27} \mathrm{H}_{44} \mathrm{NO}_{8}\right]^{+}$, 510.3061). ${ }^{1} \mathrm{H}$ and ${ }^{13} \mathrm{C}$ NMR data: see $>$ Table 1. 1D and 2D NMR spectra (gCOSY, gHSQC, gHMBC, NOESY) are displayed in the Supporting Information, Figs. 6aS to 6fS. 


\section{Compound 1b (tiliine B)}

Pale yellow oil. HR-ESI-MS: m/z 510.3089 [M + H] ${ }^{+}$(calculated for $\left.\left[\mathrm{C}_{27} \mathrm{H}_{44} \mathrm{NO}_{8}\right]^{+}, 510.3061\right) .{ }^{1} \mathrm{H}$ and ${ }^{13} \mathrm{C}$ NMR data: see $>$ Table 1. 1D and 2D NMR spectra (gCOSY, gHSQC, gHMBC, NOESY) are displayed in the Supporting Information, Figs. 7aS to 7fS.

\section{Compound 2a (tiliamine A)}

Pale yellow oil. HR-ESI-MS: m/z 512.3223 [M + H] ${ }^{+}$(calculated for $\left[\mathrm{C}_{27} \mathrm{H}_{46} \mathrm{NO}_{8}\right]^{+}$, 512.3218). ${ }^{1} \mathrm{H}$ and ${ }^{13} \mathrm{C}$ NMR data: see $>$ Table 2. 1D and 2D NMR spectra (gCOSY, gHSQC, gHMBC, NOESY) are displayed in the Supporting Information, Figs. 8aS to 8fS.

\section{Compound 2b (tiliamine B)}

Pale yellow oil. HR-ESI-MS: m/z $512.3233[\mathrm{M}+\mathrm{H}]^{+}$(calculated for $\left[\mathrm{C}_{27} \mathrm{H}_{46} \mathrm{NO}_{8}\right]^{+}$, 512.3218). ${ }^{1} \mathrm{H}$ and ${ }^{13} \mathrm{C}$ NMR data: see $>$ Table 2. 1D and 2D NMR (gCOSY, gHSQC, gHMBC, NOESY) spectra are displayed in the Supporting Information, Figs. 9aS to $9 \mathrm{fS}$.

\section{Compound 3a (tilacetine A)}

Pale yellow oil. HR-ESI-MS: m/z 554.3378 [M + H] ${ }^{+}$(calculated for $\left[\mathrm{C}_{29} \mathrm{H}_{48} \mathrm{NO}_{9}\right]^{+}$, 554.3324). ${ }^{1} \mathrm{H}$ and ${ }^{13} \mathrm{C}$ NMR data: see $>$ Table 3. 1D and 2D NMR (gCOSY, gHSQC, gHMBC, NOESY) spectra are displayed in the Supporting Information, Figs. 10aS to $10 \mathrm{fS}$.

\section{Compound $3 \mathrm{~b}$ (tilacetine B)}

Pale yellow oil. HR-ESI-MS: m/z 554.3382 [M + H] ${ }^{+}$(calculated for $\left[\mathrm{C}_{29} \mathrm{H}_{48} \mathrm{NO}_{9}\right]^{+}$, 554.3324). ${ }^{1} \mathrm{H}$ and ${ }^{13} \mathrm{C}$ NMR data: see $>$ Table 3. 1D and 2D NMR (gCOSY, gHSQC, gHMBC, NOESY) spectra are displayed in the Supporting Information, Figs. 11aS to $11 \mathrm{fS}$.

\section{Supporting Information}

LC-MS chromatograms for identification of alkaloids from Tilia extract; $\mathrm{MS}^{2}$ and UV/VIS spectra of the alkaloids; identification of sugar moiety after hydrolysis by TLC and CZE; ${ }^{1} \mathrm{H}-{ }^{13} \mathrm{C}-$, gCOSY-, gHSQC-, gHMBC-, NOESY NMR data sets of the 6 alkaloids are provided as Supporting Information.

\section{Contributors' Statement}

The manuscript was written through contributions of all authors. All authors give approval to the final version of the manuscript. Experimental work was performed by NS, MB, JS, AH.

\section{Acknowledgements}

The help of Dr. Jens Köhler for NMR measurements is gratefully acknowledged. Funding was provided from intramural grants from University of Münster, Germany (no grant numbers available).

\section{Conflict of Interest}

The authors declare the following competing financial interest: The compounds described here in this study have been recorded for patent application European Patent Application EP 20193376.9 , 28. 08. 2020.
References

[1] Committee on Herbal Medicinal Products. HMPC monograph Tiliae flosCommunity herbal monograph on Tilia cordata Miller, Tilia platyphyllos Scop., Tilia $\times$ vulgaris Heyne or their mixtures, flos. EMA/HMPC/337066/ 2011. Accessed August 6, 2020 at: https://www.ema.europa.eu/en/ medicines/herbal/tiliae-flos

[2] Committee on Herbal Medicinal Products. HMPC assessment report Tiliae flos-Assessment report on Tilia cordata Miller, Tilia platyphyllos Scop., Tilia $\times$ vulgaris Heyne or their mixtures, flos. EMA/HMPC/337067/ 2011. Accessed August 6, 2020 at: https://www.ema.europa.eu/en/ medicines/herbal/tiliae-flos

[3] Council of Europe-European Directorate for the Quality of Medicines. European Pharmacopoiea 10.0: Lime Flower-Tiliae flos. Stuttgart, Germany: Deutscher Apotheker Verlag; 2020

[4] Karioti A, Chiarabini L, Alachkar A, Fawaz Chehna M, Vincieri FF, Bilia AR. HPLC-DAD and HPLC-ESI-MS analyses of Tiliae flos and its preparations. J Pharm Biomed Anal 2014; 100: 205-214. doi:10.1016/j.jpba.2014. 08.010

[5] Negri G, Santi D, Tabach R. Flavonol glycosides found in hydroethanolic extracts from Tilia cordata, a species utilized as anxiolytics. Rev Bras Plantas Med 2013; 15: 217-224. doi:10.1590/S151605722013000200008

[6] Toker G, Aslan M, Yeşilada E, Memişoğlu M, Ito S. Comparative evaluation of the flavonoid content in officinal Tiliae flos and Turkish lime species for quality assessment. J Pharm Biomed Anal 2001; 26: 111-121. doi:10.1016/s0731-7085(01)00351-x

[7] Kram G, Franz G. Untersuchungen über die Schleimpolysaccharide aus Lindenblüten. Planta Med 1983; 49: 149-153. doi:10.1055/s-2007969836

[8] Toker G, Baser KHC, Kürkçüoglu M, Özek T. The composition of essentia oils from Tilia L. Species Growing in Turkey. J Essent Oil Res 1999; 11: 369-374. doi:10.1080/10412905.1999.9701158

[9] Symma N, Sendker J, Petereit F, Hensel A. Multistep analysis of Diol-LCESI-HRMS data reveals proanthocyanidin composition of complex plant extracts (PAComics). J Agric Food Chem 2020; 68: 8040-8049. doi:10.1021/acs.jafc.0c02826

[10] Schmidgall J, Schnetz E, Hensel A. Evidence for bioadhesive effects of polysaccharides and polysaccharide-containing herbs in an ex vivo bioadhesion assay on buccal membranes. Planta Med 2000; 66: 48-53. doi:10.1055/s-2000-11118

[11] Buchbauer G, Jirovetz L, Jäger W. Passiflora and lime-blossoms: motility effects after inhalation of the essential oils and of some of the main constituents in animal experiment. Arch Pharm 1992; 325: 247-248. doi:10.1002/ardp.19923250410

[12] Still PC, Yi B, González-Cestari TF, Pan L, Pavlovicz RE, Chai HB, Ninh TN Li C, Soejarto DD, McKay DB, Kinghorn AD. Alkaloids from Microcos paniculata with cytotoxic and nicotinic receptor antagonistic activities. J Nat Prod 2013; 76: 243-249. doi:10.1021/np3007414

[13] Chaves OS, Gomes RA, Tomaz AC, Fernandes MG, das Graças Mendes L jr., de Fátima Agra M, Braga VA, de Fátima Vanderlei Souza M. Secondary metabolites from Sida rhombifolia L. (Malvaceae) and the vasorelaxant activity of cryptolepinone. Molecules 2013; 18: 2769-2777. doi: $10.3390 /$ molecules18032769

[14] Chaves OS, Teles YC, Monteiro MM, Mendes Junior LG, Agra MF, Braga VA, Silva TM, Souza MF. Alkaloids and phenolic compounds from Sida rhombifolia L. (Malvaceae) and vasorelaxant activity of two indoquinoline alkaloids. Molecules 2017; 22. doi:10.3390/molecules22010094

[15] Noe CR, Freissmuth J. Capillary zone electrophoresis of aldose enantiomers: separation after derivatization with S-(-)-1-phenylethylamine. J Chromatogr A 1995; 704: 503-512. doi:10.1016/0021-9673(95) 00237-H 
[16] Periyannan GR, Lawrence BA, Egan AE. ${ }^{1} \mathrm{H}$ NMR spectroscopy-based configurational analysis of mono- and disaccharides and detection of $\beta$-glucosidase activity: an undergraduate biochemistry laboratory. J Chem Educ 2015; 92: 1244-1249. doi:10.1021/ed500578c

[17] Melhaoui A, Bodo B. Irnigaine and N-Methylirnigaine, two new piperidinol alkaloids from the tubers of Arisarum vulgare. Nat Prod Let 1995; 7: 101-108. doi:10.1080/10575639508043196

[18] Su Y, Xu J], Bi JL, Wang YH, Hu GW, Yang J, Yin GF, Long CL. Chemical constituents of Arisaema franchetianum tubers. J Asian Nat Prod Res 2013; 15: 71-77. doi:10.1080/10286020.2012.723202

[19] Huang W, Yi X, Feng J, Wang Y, He X. Piperidine alkaloids from Alocasia macrorrhiza. Phytochem 2017; 143: 81-86. doi:10.1016/j.phytochem. 2017.07.012

[20] Freitas TR, Danuello A, Viegas Júnior C, Bolzani VS, Pivatto M. Mass spectrometry for characterization of homologous piperidine alkaloids and their activity as acetylcholinesterase inhibitors. Rapid Commun Mass Sp 2018; 32: 1303-1310. doi:10.1002/rcm.8172

[21] Bolzani VS, Leslie Gunatilaka AA, Kingston DGI. Bioactive and other piperidine alkaloids from Cassia leptophylla. Tetrahedron 1995; 51: 5929-5934. doi:10.1016/0040-4020(95)00254-6

[22] Christofidis I, Welter A, Jadot J. Spectaline and iso-6 cassine, two new piperidin 3-ol alkaloids from the leaves of Cassia spectabilis. Tetrahedron 1977; 33: 977-979. doi:10.1016/0040-4020(77)80211-1

[23] Christofidis I, Welter A, Jadot J. Spectalinine and iso-6-carnavaline, two unprecedented piperidine alkaloids from the seeds of Cassia spectabilis. Tetrahedron 1977; 33: 3005-3006. doi:10.1016/0040-4020(77) 88038-1
[24] Luis AS, Karin JS, Schmeda-Hirschmann G, Griffith GA, Holt D], Jenkins PR. DNA binding alkaloids from Prosopis alba. Planta Med 1999; 65: 161-162. doi:10.1055/s-2006-960454

[25] Reina L, Bennadji Z, Vinciguerra V, Ferreira F, Moyna G, Menendez P. Isolation and structural characterization of new piperidine alkaloids from Prosopis affinis. Phytochem Lett 2015; 14: 265-269. doi:10.1016/j. phytol.2015.10.022

[26] Feng SX, Lin LD, Xu HH, Wei XY. Two new piperidine alkaloids from the leaves of Microcos paniculata. J Asian Nat Prod Res 2008; 10: 1155-1158. doi:10.1080/10286020802361289

[27] Zhang G, Zhang N, Xu L, Wu HT, Chen D, Lin QH, Luo LZ. A new piperidine alkaloid from the leaves of Microcos paniculata L. Nat Prod Res 2017; 31: 169-174. doi:10.1080/14786419.2016.1224868

[28] Bandara KA, Kumar V, Jacobsson U, Molleyres LP. Insecticidal piperidine alkaloid from Microcos paniculata stem bark. Phytochem 2000; 54: 29 32. doi:10.1016/S0031-9422(00)00025-X

[29] Aguinaldo AM, Read RW. A major piperidine alkaloid from Microcos philippinensis. Phytochem 1990; 29: 2309-2313. doi:10.1016/0031-9422 (90)83058-9

[30] Lindquist N, Shigematsu N, Pannell L. Corydendramines A and B, defensive natural products of the marine hydroid Corydendrium parasiticum. J Nat Prod 2000; 63: 1290-1291. doi:10.1021/np000050h

[31] Albersheim P, Nevins DJ, English PD, Karr A. A method for the analysis of sugars in plant cell-wall polysaccharides by gas-liquid chromatography. Carbohydr Res 1967; 5: 340-345. doi:10.1016/S0008-6215(00)80510-8 